\title{
Recent Progress in Environmental Toxins-Induced Cardiotoxicity and Protective Potential of Natural Products
}

\section{OPEN ACCESS}

Edited by:

Michat Tomczyk,

Medical University of Bialystok, Poland

Reviewed by:

Milton Prabu,

Annamalai University, India

Magdalena Kozłowska,

Medical University of Bialystok, Poland

*Correspondence:

Bikui Zhang

505995@csu.edu.cn

Wenqun $\mathrm{Li}$

liwq1204@csu.edu.cn

Specialty section:

This article was submitted to

Ethnopharmacology,

a section of the journal

Frontiers in Pharmacology

Received: 23 April 2021 Accepted: 28 June 2021

Published: 08 July 2021

Citation:

Yang Y, Wei S, Zhang B and Li W

(2021) Recent Progress in

Environmental Toxins-Induced Cardiotoxicity and Protective Potential

of Natural Products.

Front. Pharmacol. 12:699193.

doi: 10.3389/fphar.2021.699193

\author{
Yuanying Yang ${ }^{1,2}$, Shanshan Wei ${ }^{1,2}$, Bikui Zhang ${ }^{1,2 *}$ and Wenqun $L i^{1,2 *}$ \\ ${ }^{1}$ Department of Pharmacy, The Second Xiangya Hospital, Central South University, Changsha, China, ${ }^{2}$ Institute of Clinical \\ Pharmacy, Central South University, Changsha, China
}

Humans are unconsciously exposed to environmental toxins including heavy metals as well as various pesticides, which have deleterious effects on human health. Accumulating studies pointed out that exposure to environmental toxins was associated with various cardiopathologic effects. This review summarizes the main mechanisms of cardiotoxicity induced by environmental toxins (cadmium, arsenic and pesticides) and discusses the potential preventive effects of natural products. These findings will provide a theoretical basis and novel agents for the prevention and treatment of environmental toxins-induced cardiotoxicity. Furthermore, the limitations of current studies, future needs and priorities are discussed.

Keywords: environmental toxins, cadmium, arsenic, pesticides, cardiotoxicity, natural products

\section{INTRODUCTION}

The term "toxicity" refers to the relative ability of exogenous chemical substances to cause direct or indirect damage after contacting with living organisms or entering living organisms. Toxicity is closely related to dose, route of exposure, and duration of exposure. Accumulating evidence demonstrated the toxicity of drugs or other environmental factors to organs and systems. In mammals, aminoglycoside compounds are selectively toxic to renal proximal tubule cells and sensory hair cells of inner ear, resulting in nephrotoxicity and ototoxicity (Kros and Steyger, 2019). In a recent prospective study, it was found that approximately one out of 2,300 amoxicillin-clavulanic acid users experienced liver damage (Björnsson and Hoofnagle, 2016). The heavy metal lead, as a neurotoxin, has an adverse effect on human cognition and behavior (Rocha and Trujillo, 2019). Although the whole organs in the human body are vulnerable, heart as a vital organ is noteworthy.

Heart disorders such as arrhythmias and ischemic heart disease, are one of the leading causes of morbidity and mortality in the world (Al-Mallah et al., 2018). In addition to pathological factors, drug factors and environmental factors can also lead to heart disease. Cardiomyocytes are considered to be the main target of doxorubicin cardiotoxicity, and the clinical application of doxorubicin is limited by cumulative and dose-related cardiotoxicity, which may lead to congestive heart failure ( $\mathrm{Yu}$ et al., 2018). In the past few decades, evidence on the role of exposure to environmental toxins in cardiac damage has increased rapidly.

Environmental toxins, including heavy metals, pesticides, petroleum by-products and other toxic chemicals, are not easily degraded and have a long residual period. Moreover, they can be enriched in the human body through bioconcentration and food chain, thereby causing deleterious health effects. Heavy metals refer to inorganic elements with a density greater than $5 \mathrm{~g} / \mathrm{cm}^{3}$ which can be classified into two groups based on their toxicity: essential and non-essential heavy metal. 1) Essential heavy metals are 
harmless or relatively less harmless at low concentration ( $\mathrm{Zn}, \mathrm{Cu}, \mathrm{Fe}$, and Co). 2) Non-essential metals are highly toxic even at low concentration (Cd, Hg, As, and Cr) (Kim et al., 2019). Metalloids such as arsenic usually fall into the category of heavy metals due to its similar chemical properties and environmental behavior (Yang et al., 2018). Heavy metal contamination in water and soil has rapidly increased during the last few decades due to fossil fuel combustion (McConnell and Edwards, 2008), urban waste disposal, mining and smelting, and the application of fertilizers and pesticides ( $\mathrm{Hu}$ and Cheng, 2013; Kapusta and Sobczyk, 2015). Recent studies have provided convincing evidence that exposure to heavy metals is associated with increased risks of diabetes and hypertension ( $\mathrm{Hu}$ and Cheng, 2013; Planchart et al., 2018), which are strong risk factors for cardiovascular diseases. Exposure to arsenic is associated with various cardiopathologic effects. For example, arsenic exposure may cause arrhythmia by prolonging the QT interval and accelerating intracellular calcium overload (Manna et al., 2008). As a toxic heavy metal, cadmium can damage the cardiovascular system, leading to heart disorders such as myocardial infarction, cardiomyopathy, and heart failure (Mollaoglu et al., 2006; Everett and Frithsen, 2008; Peters et al., 2010).

The post World War II era witnessed a great change in agriculture practices, which led to the emergence of mechanization and the development of various chemical pesticides. Pesticides are often used to keep crops healthy and free from disease and pests. Moreover, pesticides have a wider range of uses, such as acaricides and rodenticides for non-plant use to control disease vectors. The main chemical pesticides include organochlorines, organophosphates and carbamates. With the expansion of agricultural production scale, the application of pesticides has shown a sharp upward trend. The use of pesticides has indubitably increased food production and eased the problem of famine to a certain extent, but the threat of pesticides to life and health has gradually emerged and cannot be ignored. Rare arrhythmias can appear later after organophosphorus poisoning, even if the state of illness improves markedly, which may be caused by cardiotoxic effects, metabolic acidosis and electrolyte disturbances (Georgiadis et al., 2018). The cardiotoxic effect of aluminum phosphide leads to oxidative stress, deplete myocardial energy ATP and induce apoptosis in animals (Baghaei et al., 2016). Paraquat poisoning induces alterations in myocardial function and left ventricular geometry, such as enlarged left ventricular end-systolic diameter (Wang et al., 2014).

Natural products with multiple biological activities are becoming a significant beginning of novel agents and own various pharmaceutical development potentials. This review summarizes current understanding of environmental toxinsinduced cardiotoxicity and discusses the potential preventive effects of natural plants.

\section{MECHANISMS OF ENVIRONMENTAL TOXINS-INDUCED CARDIOTOXICITY}

\section{Oxidative Stress}

Oxidative stress is a typical phenomenon of many cardiovascular abnormalities, as well as the most widely studied and recognized mechanism of iatrogenic cardiotoxicity of environmental toxins. The expression and coordinated induction of antioxidant enzymes are mediated by the antioxidant response element, which is a key mechanism to resist chemically induced oxidative/electrophilic stress. Nuclear factor erythroid-2 related factor $2(\mathrm{Nrf} 2)$ is an important transcription factor that regulates cellular oxidative stress, which binds to antioxidant response element sites and regulates antioxidant-mediated gene expression and induction (Jaiswal, 2004). Endogenous antioxidants including superoxide oxide dismutase (SOD), catalase (CAT) and glutathi-one peroxidase (GPx) have been identified as Nrf2-regulated antioxidant enzymes and constitute a line of defense against reactive oxygen species (ROS), which play a vital role in maintaining redox balance and protecting cells from oxidative damage. Once the production of ROS and the internal antioxidant defense system is out of balance, cells will experience oxidative stress (Das et al., 2016). A study conducted by Doroshow et al. (1980) demonstrated that the heart, compared to liver, has a much lower concentration of endogenous antioxidants, which indicates that the heart may be more sensitive to peroxidation damage due to its limited antioxidant capacity in scavenging oxygen free radicals.

Early studies have shown that heavy metal Cd promotes the release of iron in biomembrane and this free iron participates in Fenton-type reactions, thus generating ROS (Casalino et al., 1997). Another study reported that Cd may competitively bind to the $\mathrm{q}_{0}$ site of cytochrome $\mathrm{b}$ of mitochondrial complex III, leading to the accumulation of semiubiquinone at the $\mathrm{q}_{0}$ site, generating ROS and causing oxidative stress (Wang et al., 2004). Moreover, as a thiol affinity metal, free $\mathrm{Cd}$ mainly targets intracellular glutathione $(\mathrm{GSH})$ - a reactive oxygen scavenger. The depletion of the GSH pool will lead to insufficient clearance of $\mathrm{Cd}$, which triggers the disorder of the cell redox balance (Nair et al., 2013). The same conclusion can also be obtained in the study of the cardiotoxicity mechanism of arsenic and other heavy metals (Shimizu et al., 1998). It is speculated that the overproduction of mitochondrial reactive oxygen species (mtROS) may lead to the occurrence of various cardiovascular diseases (Li et al., 2013a). Arsenic-induced overproduction of mtROS destroys myocardial mitochondrial complex I-IV, thereby down-regulating the expression of mitochondrial respiratory chain complex (Adil et al., 2015). Earlier, it was also believed that the increased production of mtROS caused mitochondrial swelling and abnormal mitochondrial membrane potential.

Just like many drugs, lithium may directly or indirectly induce oxidative stress through mitochondria via the redox cycling or by promoting iron accumulation and oxidation/nitrification modification of essential mitochondrial proteins; in this way, it plays a key role in the development of myocardial dysfunction (Castro et al., 2011).

Fine particulate matter (PM2.5) can produce a large number of ROS and reactive nitrogen species (RNS), caused the unbalance of cell homeostasis and then excessive ROS may result in damage of nuclear DNA and mitochondria including mitochondrial permeabilization, membrane potential decreasing and mitochondrial swelling, followed by further apoptosis in cardiomyocytes (Yang et al., 2018). 
It is reported that the redox state of experimental animals exposed to organophosphate is generally abnormal. Georgiadis and his colleagues pointed out that oxidative stress is the main mode of action of organophosphates, leading to side effects on myocardial tissue (Georgiadis et al., 2018). The fact that longterm exposure to organophosphorus pesticides inhibit the activity of cholinesterase, increased the production of ROS, which disrupts the balance of antioxidant enzymes, thereby leading to oxidative stress (Razavi et al., 2015; Asghari et al., 2017a). As for other pesticides, most of them will experience the same process. Phosphorus aluminum can inhibit antioxidant enzymes and iron release from transferrin, causing Fenton's and HaberWeiss reactions to produce iron-catalyzed ROS, thereby inducing oxidative stress (Anand et al., 2011). Paraquat can trigger a continuous redox cycle reaction, producing a large amount of ROS, leading to oxidative stress and impairing myocardial contractility, ultimately causing heart failure (Wang et al., 2017). Chlorpyrifos can cause myocardial tissue disorders, myocardial fiber degeneration and connective tissue edema. It is speculated that these changes may be due to increased secretion of mtROS and oxidative stress in heart tissue, which lead to decreased mitochondrial energy, decreased secretion of proteolytic enzymes, and DNA disintegration to induce apoptosis (Kapoor and Kakkar, 2014).

\section{Changes in Cardiac Ion Channels and Ion Disorders}

Cardiomyocytes are rich in sodium channels, and pyrethroids are believed to be able to convert the voltage-dependent activation and inactivation of sodium channels into hyperpolarization potentials. Type I pyrethroid, tefluthrin, and type II pyrethroid, fenpropathrin and a-cypermethrin, alter the time course of sodium channel current by changing the relative ratio of fast and slow inactivation current, modify the voltage dependence of I $(\mathrm{Na})$, prolong the ventricular action potential and cause postdepolarization, indicating an arrhythmogenic activity (Spencer et al., 2001). Ion content plays a role in many physiological processes. Proper ion concentration is essential to ensure the normal function of the entire body, especially the heart. Atrazine induced cardiotoxicity via the modulation of cardiac ATPase including $\mathrm{Na}^{+}-\mathrm{K}^{+}$-ATPase, $\mathrm{Ca}^{2+}$-ATPase, $\mathrm{Mg}^{2+}$-ATPase and changes in the transcription of pump subunits, leading to ionic disorder (Lin et al., 2016). PM2.5 significantly inhibited mitochondrial $\mathrm{Na}^{+}-\mathrm{K}^{+}$-ATPase and $\mathrm{Ca}^{2+}$-ATPase activities, implying that PM2.5 causes dysfunction of sodium pump and calcium pump (Li et al., 2015). One of the typical features of $\mathrm{NaAsO}_{2}$-induced cardiotoxicity is the accumulation of intracellular calcium (Chen et al., 2010). Myocardial L-type calcium channel plays a vital role in maintaining calcium ion balance. The accumulation of intracellular calcium in myocardial tissue may cause various abnormalities, including ventricular arrhythmia and systolic dysfunction (Ficker et al., 2004).

\section{Inflammation}

Excessive toxic metals impair immune function and the accumulation of immune complexes, and lead to cardiovascular diseases through a series of interrelated processes, such as the uncontrolled release of inflammatory cytokines. Cd poisoning increases the production of TNF- $\alpha$, IL-2 and IL- 6 by stimulating circulating monocytes and tissue macrophages, leading to the synthesis and release of proinflammatory cytokines, which may be attributed to the increase in oxidized low-density lipoprotein (ox-LDL) caused by cadmium (Janabi et al., 2000). Arsenic may directly induce atherosclerosis by increasing the mRNA transcription of growth factors such as granulocyte-macrophage colony stimulating factor (GMCSF) and TGFa, and inflammatory cytokines such as TNF- $\alpha$ and IL-6 (Alamolhodaei et al., 2015) and multiple evidence indicate atherosclerosis is closely related to ischemic heart disease.

\section{PROTECTIVE EFFECTS OF NATURAL PRODUCTS AGAINST ENVIRONMENTAL TOXINS-INDUCED CARDIOTOXICITY}

\section{Cadmium-Induced Cardiotoxicity}

Heavy mental Cadmium (Cd), a ubiquitous environmental pollutant, was listed as the first category human carcinogen by the International Agency for Research on Cancer (IARC) in 1993. Human exposure to $\mathrm{Cd}$ can be through many sources, including eating food contaminated by pesticides and fertilizers, smoking cigarettes, and working in cadmium-contaminated workplace, with smoking being a major risk factor (Paschal et al., 2000). Like other toxic heavy metals, Cd is greatly concentrated in the upper levels of food chain (Järup and Akesson, 2009). Its extremely long biological half-life (about 20-30 years) and low rate of excretion from the body lead to Cd continuous bioaccumulation in soft tissues (Branca et al., 2018), which inevitably induces acute and chronic tissue damage and does great harm to important organs, such as liver (Rikans and Yamano, 2000) and kidney (Satarug, 2018), even our heart (Ali et al., 2020), depending on the time and dose. It has been long realized that the toxicity induced by $\mathrm{Cd}$ triggers biochemical and physiological changes in the heart. A growing number of data has shown that excessive exposure to $\mathrm{Cd}$ is closely related to cardiovascular disease (Peters et al., 2010), including cardiac death and myocardial infarction (Everett and Frithsen, 2008), according to the epidemiological studies.

It is universally acknowledged that oxidative stress is the major event induced by Cd poisoning (Liu et al., 2009). Cd exerts toxic effects via the generation of free radicals and subsequent ROS accumulation, causing tissue damage to a great extent (Gupta et al., 2017). Given the correlation between Cd exposure and oxidative stress, attention turned to focus on natural products rich in antioxidants in order to inhibit the cardiotoxicity mediated by $\mathrm{Cd}$. Documented probable cadmium exposure routes and mechanisms of natural products against Cdinduced cardiotoxicity are presented in Figure $\mathbf{1}$.

\section{Natural Products}

Accumulating studies has proved the beneficial effects of natural products for its protection against Cd induced toxicity. Quercetin 

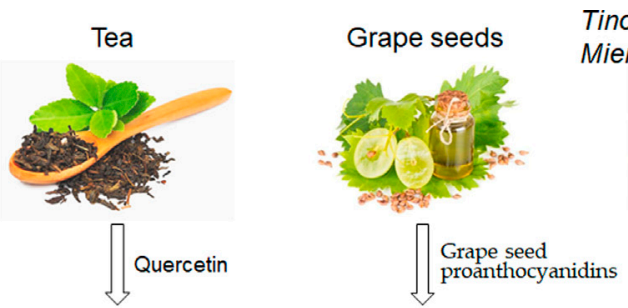

Tinospora cordifolia (Willd.)

Miers ex Hook.f. \& Thomson
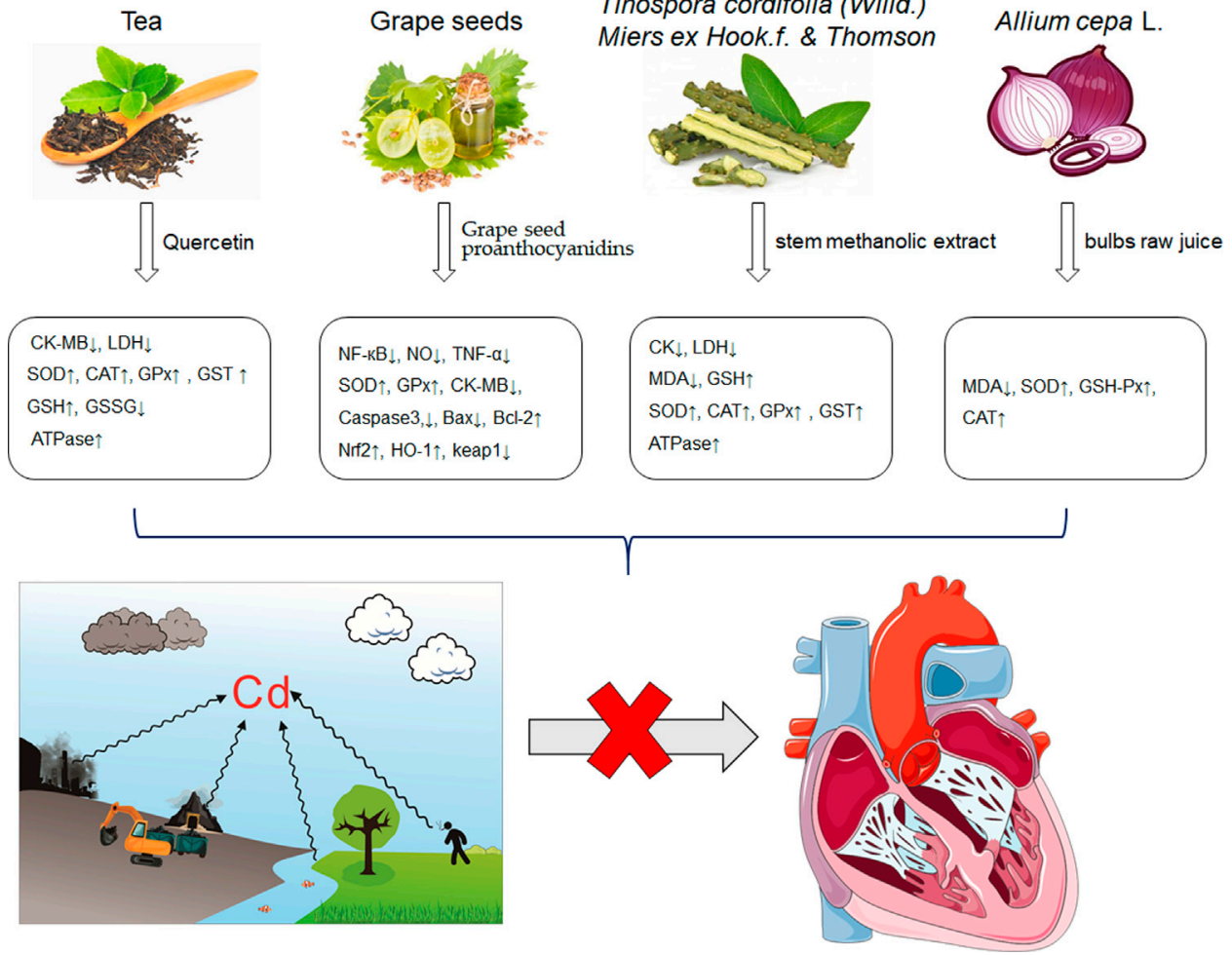

FIGURE 1 | The cadmium exposure routes and protective mechanisms of natural products against cadmium-induced cardiotoxicity. CK-MB, creatine kinase-MB; LDH, Lactic dehydrogenase; SOD, Superoxide dismutase; CAT, catalase; GPx, Glutathione peroxidase; GST, Glutathione S-Transferase; GSH, glutathione; NF-кB, nuclear factor-кB; NO, nitric oxide; TNF- $\alpha$, tumor necrosis factor- $\alpha$; Nrf2, NF-E2-related factor 2; HO-1, heme oxygenase-1; MDA, Malondialdehyde.

is known as robust antioxidant and free radical scavenger against oxidative stress (Xu et al., 2019). A study conducted by Milton Prabu et al. evaluated the effects of quercetin on cardiac marker enzymes, lipid peroxidation products, lipid profile, membrane bound ATPases and antioxidant status in Cd-intoxicated rats, which demonstrated that quercetin pretreatment at a dose of $50 \mathrm{mg} / \mathrm{kg}$ body mass (bm) per day could prevent oxidative damage to the rat hearts when supplemented with $\mathrm{Cd}$ ( $5 \mathrm{mg} / \mathrm{kg} \mathrm{bm} /$ day) for 28 days (Milton Prabu et al., 2013).

Grape seed proanthocyanidins, effective bioactive components extracted from natural grape seeds, have drawn a great slew of attention due to their extensive biological and pharmacological properties (Bors et al., 2001; Bagchi et al., 2002). In Cdadministered $\left(\mathrm{CdCl}_{2}, 5 \mathrm{mg} / \mathrm{kg} \mathrm{bm}\right.$, 4 weeks $)$ male Wistar rats, grape seed proanthocyanidins ( $100 \mathrm{mg} / \mathrm{kg} \mathrm{bm}, \mathrm{p}$. o.) was found to own cardioprotective effects by functioning as in-vivo antioxidant and was capable of inhibiting the membrane disturbances in cardiomyocytes, apoptotic pathway and inflammation. Besides, the signals from phenolic antioxidants present in grape seed proanthocyanidins lead to phosphorylation of Nrf2 and/or redox modulation of Nrf2/Keap1, leading to separation of Nrf2 from Nrf2/Keap1, thereby restoring Nrf2 expression in the heart of rats. Therefore, grape seed proanthocyanidins recuperated the Cd-induced oxidative stress mediated cardiac dysfunction (Nazimabashir et al., 2015).

\section{Plant Extracts}

Tinospora cordifolia (Willd.) Miers ex Hook. f. \& Thomson, belonging to the family Menispermaceae Juss., is a medicinal herb used in Ayurveda for treating varied metabolic disorders and toxic conditions (Patgiri et al., 2014; Singh et al., 2015). Antioxidant and cardioprotective activity of Tinospora cordifolia (Willd.) Miers ex Hook. f. \& Thomson against streptozotocin induced diabetic rats has been reported (Sharma et al., 2011). Moreover, its stem methanolic extract for male albino Wistar rats can significantly attenuate $\mathrm{Cd}$ induced lipid peroxidation and protein carbonylation, reduced heart histological changes and decreased the activities of membrane bound ATPases at dose of $5 \mathrm{mg} \mathrm{Cd} / \mathrm{kg}$ bm (Priya et al., 2017).

Allium cepa L. (Onion), one of the most widely and commonly consumed vegetables in the genus Allium L., shows considerable antioxidant value (Suru, 2008). Onion consumption correlates with low rates of coronary heart disease (Hertog et al., 1993). Several studies have demonstrated cardioprotective effects of $A$. cepa extract by lowering serum cholesterol and blood pressure. In $\mathrm{Cd}$ administered $(1 \mathrm{mg} / \mathrm{kg}$ bm, s. c.) male Sprague-Dawley rats, A. cepa extract effectively attenuated Cd-induced histological alterations, apoptosis in the cardiomyocytes and decreased levels of the enzymatic antioxidants 


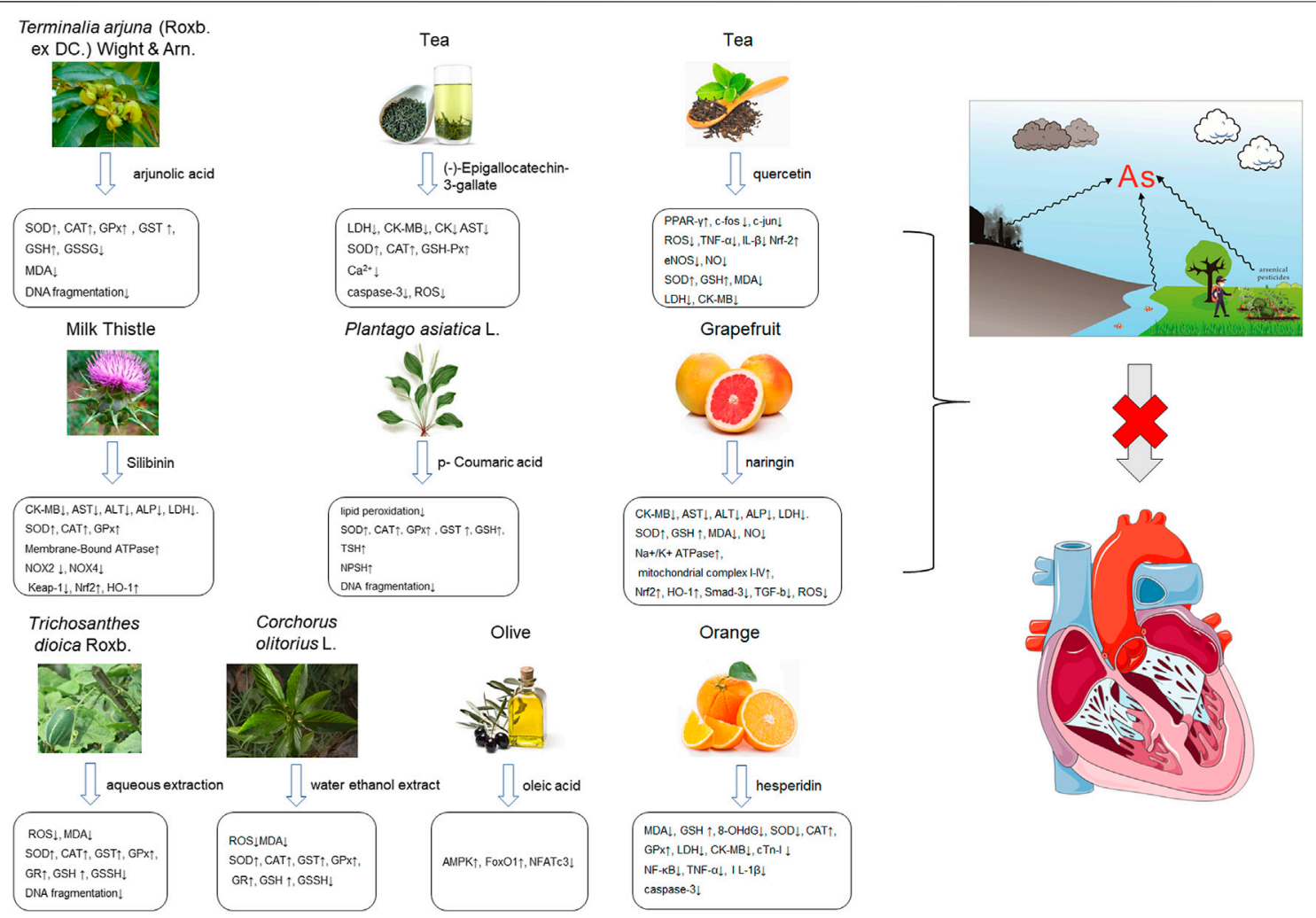

FIGURE 2 | The arsenic exposure routes and protective mechanisms of natural products against arsenic-induced cardiotoxicity. AST, Aspartate transaminase; ALT, alanine aminotransferase; ROS, reactive oxygen species; IL- $\beta$, interleukin- $\beta$; eNOS, endothelial NOS; NOX2, NADPH oxidase two; NOX4, NADPH oxidase four; $\mathrm{TSH}$, total sulfhydryl; NPSH, non-protein sulfhydryl; AMPK, adenosine monophosphate-activated protein kinase; GR, glutathione reductase.

probably via its antioxidant and anti-apoptotic activity (Alpsoy et al., 2014).

Summarized above the mentioned, although the natural products supplementation has a protective effect on Cdinduced oxidative heart damage in rats, the exact molecular mechanism has not been elucidated. Moreover, with the exception of in-vivo studies, the protective activity of these natural products in Cd-induced cardiotoxicity should be verified through in-vitro studies.

\section{Arsenic-Induced Cardiotoxicity}

Arsenic is naturally occurring metalloid element that abundant in Earth's crust and biosphere. Due to its high water-solubility, the main source of human exposure to arsenic is drinking water contaminated with arsenic (Mathews et al., 2013). In addition, the use of arsenic-containing herbicides, pesticides, and burning fossil fuels can cause a high risk of arsenic poisoning (Mandal et al., 2001; Mazumder et al., 2010; Shivakumar et al., 2014). Once absorbed, arsenic is redistributed to almost the entire body organ system, including the heart (Ratnaike, 2003; Manna et al., 2008). Arsenic exposure gives rise to myocardial damage, arrhythmia (Manna et al., 2008) and left ventricular hypertrophy (Pichler et al., 2019), which correlates with pathogenesis of myocardial tissue. The possible mechanisms of arsenic-induced cardiotoxicity mainly include oxidative stress, DNA fragmentation, changes in cardiac ion channels (Alamolhodaei et al., 2015). At present, there are various drugs for the treatment of the above-mentioned arsenic-induced heart diseases, such as commonly used angiotensin-converting enzyme inhibitors and $\beta$-blockers (Curigliano et al., 2016). However, the non-negligible side effects limit their clinical application. In recent years, more and more attention has been focused on the chemical components extracted from natural products due to their broad pharmacological activity and low toxicity. Scientists hope to find inspiration from it and explore new methods for the treatment of arsenic-induced cardiotoxicity. As is depicted in Figure 2, the possible arsenic exposure routes and mechanism of natural products against cadmium-induced cardiotoxicity have been summarized.

\section{Natural Products}

Arjunolic acid, one of the constituents existed in the bark of Terminalia arjuna (Roxb. ex DC.) Wight \& Arn., has been shown to provide significant cardioprotection in isoproterenol-induced myocardial necrosis (Sumitra et al., 2001). Manna et al. mentioned that arsenic poisoning (10 mg/kg bm, p. o., 2 days) can cause severe oxidative damage to the heart tissue in mice, which can be prevented by treating with arjunolic acid $(20 \mathrm{mg} / \mathrm{kg}$ $\mathrm{bm}, 4$ days). The overall preventive effect of arjunolic acid may be due to its scavenging free radicals and metal chelating properties, 
thereby reducing the arsenic load in the cells (Manna et al., 2008). Another research revealed that arjunolic acid could regulate oxidative phosphorylation in the mitochondria and subsequently inhibit ROS generation through abrogated p47phox-Ser345 phos phorylation in stimulated and myocardial infarction neutrophils, which is the first report showing the protective effect of arjunolic acid on p47phox phosphorylation and mitochondrial bioenergetics (Miriyala et al., 2015). Moreover, arjunolic acid as a Peroxisome Proliferator-Activated Receptora (PPAR $\alpha$ ) agonist up-regulates PPAR $\alpha$, leading to repression of TGF- $\beta$ signaling, especially by inhibiting TGF- $\beta$ activated kinaselphosphorylation, which reduces the activity of p38MAPK and NFkBp65, ultimately reversing hypertrophy-related myocardial fibrosis. These results provide new insights for in-depth exploration of the protective mechanism of arjunolic acid against arsenic-induced cardiotoxicity.

(-)-Epigallocatechin-3-gallate, the most abundant and active compound in green tea, possesses a potent antioxidant capacity and exhibits versatile pharmacological activities (Chakrawarti et al., 2016). Treatment with (-)-epigallocatechin-3-gallate $(50 \mathrm{mg} / \mathrm{kg}$ bm, i. g., 30 days $)$ significantly attenuated myocardial injury, suppressed oxidative damage and myocardial apoptosis induced by arsenic in rats $(50 \mathrm{mg} / \mathrm{kg} \mathrm{bm}$, 30 days) and $\mathrm{H} 9 \mathrm{c} 2$ cells $(1 \mu \mathrm{M})$. This study proved that (-)-epigallocatechin-3-gallate plays a protective role by reducing the production of ROS, maintaining the intracellular calcium ion concentration, and reducing activation of caspase- 3 (Sun et al., 2016). The protective effect of (-)-epigallocatechin-3gallate on arsenic-induced cardiotoxicity was evaluated in vivo and in vitro, and the mechanism may be attributable to its potent antioxidant capacity.

The plant of Madhuca indica J. F. Gmel., belonging to the family Sapotaceae Juss., commonly known as Mahua (Mohod et al., 2016), possesses a robust inhibitory effect on oxidative stress and inflammation. Its bioactive component extraction-quercetin has been proven to own the potential to fight against cardiotoxicity induced by isoproterenol and ischemia/reperfusion injury ( $\mathrm{Li}$ et al., 2013b; Chen et al., 2013). Mukherjee et al. found that administration of quercetin (10 and $20 \mathrm{mg} / \mathrm{kg} \mathrm{bm}$, p. o.) showed a significant protective effect against arsenic-induced ( $5 \mathrm{mg} / \mathrm{kg} \mathrm{bm}, 28$ days) oxido-nitrosative stress and myocardial injury by regulating Nrf2, PPAR- $\gamma$, and apoptosis (c-fos and c-jun) (Mukherjee et al., 2017).

Silibinin is a polyphenolic flavonoid extracted from the seeds of milk thistle (Verdura et al., 2018), possessing strong antioxidant and cardioprotective activities (Sheta et al., 2020). It has been successfully employed as a protective agent against arsenic-induced in vivo model of hepatotoxicity (Muthumani and Prabu, 2012). Pre-administration of silibinin $(75 \mathrm{mg} / \mathrm{kg} \mathrm{bm}$, 28 days) in arsenic-intoxicated ( $5 \mathrm{mg} / \mathrm{kg} \mathrm{bm}$, p. o., 28 days) rats shows potent protective efficacy against oxidative stress and cardiac injury. The treatment of silibinin facilitates the restoration of antioxidant status and normal histological architecture of cardiac tissue by inhibiting the induction of prooxidants (e.g., NOX2 and NOX4) and enhancing antioxidants (Muthumani and Prabu, 2014). p- Coumaric acid is a naturally occurring hydroxycinnamic acid derivative which is widely found in fruits and vegetables as a dietary polyphenol. According to Prasanna et al. (2013), p-coumaric acid has a protective effect similar to the standard antioxidant vitamin $\mathrm{C}$ on the rat heart damage caused by the pretreatment of sodium arsenite $(5 \mathrm{mg} / \mathrm{kg} \mathrm{bm}, 30$ days $)$ with respect to oxidative stress and cardiac tissue markers due to its antioxidant properties. Subsequent experiments detected changes in the mRNA expression profiles of inflammatory cytokines, transcription factors, MAP kinases and apoptotic proteins in myocardial tissue. The results show that daily oral $p$-coumaric acid (75 and $100 \mathrm{mg} / \mathrm{kg} \mathrm{bm,} 30$ days) before sodium arsenate exposure can regulate the changes in the above-mentioned mRNA expression profile (Prasanna and Rasool, 2014). However, further studies should be performed to identify the exact mechanism on the protective effects of $p$-coumaric acid against arsenic toxicity.

Oleic acid, a natural triterpene compound mainly found in olive oil, has been shown to have therapeutic potential for improving pathological conditions including CVDs (KrisEtherton, 1999). Samanta et al. pointed out that arsenic can cause cardiac hypertrophy in both mice and rat $\mathrm{H} 9 \mathrm{c} 2$ cardiomyocytes (Samanta et al., 2020). Interestingly, they observed that oleic acid $(100 \mu \mathrm{M})$ reduced the expression of NFATc3 by activating AMPK and increasing the localization of FoxO, thereby helping to relieve cardiac hypertrophy induced by arsenic $(1 \mu \mathrm{M})$ in $\mathrm{H} 9 \mathrm{c} 2$ cells. Oleic acid $(12.5 \mathrm{mg} / \mathrm{kg} \mathrm{bm}$, 14 days) has also been observed to help improve cardiac hypertrophy in arsenic-exposed mice (arsenic trioxide, $4 \mathrm{mg} / \mathrm{kg}$ bm, i. p., at every alternate 2 days for 6 weeks). AMPK-FoxO1NFATc3 pathway acting in arsenic-mediated cardiac hypertrophy is a novel finding, which contributes to find out novel avenues to treat the condition.

Ellagic acid, a dimeric derivative of gallic acid, is a natural polyphenol component widely found in various fruits and nuts. Ellagic acid treatment $(30 \mathrm{mg} / \mathrm{kg} \mathrm{bm}, 14$ days) could reduce oxidative stress by reducing the levels of MDA and NO and enhancing the activity of endogenous antioxidant enzymes such as CAT, SOD, GPx, thereby effectively alleviating the cardiotoxicity induced by arsenic ( $10 \mathrm{mg} / \mathrm{kg} \mathrm{bm,} \mathrm{p.} \mathrm{o.,} 21$ days) (Goudarzi et al., 2018). However, further research is needed to accurately understand the underlying cellular mechanisms.

Naringin is a flavanone glycoside with antioxidant, antiinflammatory and anti-apoptotic efficacy, mainly found in citrus fruits, especially in the peels of tangerines, sweet oranges and lemons. Naringin (40 and $80 \mathrm{mg} / \mathrm{kg}$, p. o., 28 days) can reverse the significant changes in electrocardiogram, hemodynamics and left ventricular contractile function caused by chronic administration of sodium arsenite $(5 \mathrm{mg} / \mathrm{kg} \mathrm{bm}, \mathrm{p}$. o., 28 days). It was testified that naringin ameliorates arseniteinduced cardiotoxicity and hyperlipidemia via regulation of TGF-b/Smad-3 and Nrf-2/HO-1 pathways along with a reduction in myocardial apoptosis (Adil et al., 2016). Hesperidin, an isomer of naringin, similarly shows a robust protective potential against sodium arsenite-induced $(10 \mathrm{mg} / \mathrm{kg}$ bm, 15 days) cardiotoxicity by reducing oxidative stress, apoptosis and preventing inflammation (Kuzu et al., 2021). 


\section{Plant Extracts}

Trichosanthes dioica Roxb., commonly known as parwal, is mainly cultivated as a vegetable distributed in India (Kumar et al., 2012). T. dioica root has been reported to possess some pharmacological properties, including anti-inflammatory and antioxidant activity (Bhattacharya et al., 2011; Bhattacharya and Haldar, 2012). Bhattacharya et al. indicated that T. dioica root treatment prior to arsenic intoxication $(10 \mathrm{mg} / \mathrm{kg} \mathrm{bm}, \mathrm{p}$. o., 8 days) possessed remarkable alleviative effect against arsenicinduced cardiotoxicity in Wistar albino rats, as evidenced by significant prevention of alterations in body weight, heart weight, and hematological and serum biochemical parameters (Bhattacharya and Haldar, 2013). In addition, T. dioica root treatment significantly modulated all of the myocardial antioxidative parameters and reduced DNA fragmentation. The experiment also proved that at higher doses, the effect of T. dioica root is comparable to that of ascorbic acid and quercetin. It is speculated that the active ingredient may be cucurbit type triterpene aglycone. The alleviative effect of $T$. dioica root against arsenic-induced (10 mg/kg, p. o., 8 days) cardiotoxicity is also reflected in aqueous extract of its fruit (Bhattacharya et al., 2014).

Corchorus olitorius L. belongs to the family Malvaceae Juss. Its leaves and tender stems are rich in several phenolic antioxidative compounds (Ndlovu et al., 2020). According to Das et al., oral administration of aqueous extract of $C$. olitorius leaves prior to $\mathrm{NaAsO}_{2}$-intoxication significantly protected cardiac tissue against arsenic-induced (10 mg/kg bm, p. o., 10 days) oxidative impairment and prevented hyperlipidemia and DNA fragmentation (Das et al., 2010). The cardioprotective effect may be due to the presence of substantial quantity of phytophenolics and flavonoids in the extract.

In addition to looking for new agents with the potential to combat environmental toxin-induced cardiotoxicity, the current focus has shifted to determine crucial signaling molecules/ pathways in environmental toxin-induced cardiotoxicity. The up-regulation of pro-apoptotic proteins Bax, caspase-3, c-fos and $\mathrm{c}$-jun and the down-regulation of anti-apoptotic protein TGF- $\beta$ and Bcl-2 are involved in arsenic-induced cardiomyocyte apoptosis. Studies have demonstrated that arsenic-induced elevated oxidative stress is associated with alteration in the Nrf-2/HO-1 pathway. Besides, Arsenicinduced cardiac hypertrophy is mediated by reducing the expression of AMPK and FoxO1, thereby increasing the expression of NFATc3. Collectively, studying the signaling pathways acting in arsenic-induced cardiotoxicity will help to find novel therapeutic avenues. However, the exact molecular target of natural products remained unclear. Trace its root, lack of knockdown or overexpression methods to verify the aforementioned signaling molecules, and even no gene knockout animal models are used to evaluate the cardioprotective activity of natural products.

\section{Pesticide-Induced Cardiotoxicity}

Pesticides is one of the agricultural chemicals with the largest consumption and the most abundant categories, which play a vital role in increasing agricultural production and solving human food problems. However, the use of pesticides inevitably becomes an important factor in environmental pollution. Pesticides are inherently toxic to living organisms, so its adverse effects on humans and other organisms are inevitable. A large amount of epidemiological and experimental evidence shows that there is a connection between exposure to pesticides and the incidence of multiple human diseases (Mostafalou, 2012). Exposure to pesticides has been associated with several cardiovascular complications including electrocardiogram abnormalities, myocardial infarction, functional remodeling, histopathological insults, such as hemorrhage, vacuolization, signs of apoptosis and degeneration. In addition, it also includes increased systemic and cardiac-tissue-specific oxidative stress and DNA alterations in cardiac cells that could lead to functional impairment (Georgiadis et al., 2018). Early studies have shown that pesticide chemicals may induce oxidative stress, leading to the production of free radicals and alterations in the antioxidant or oxygen free radical scavenging enzyme system (Banerjee et al., 1999). Growing evidence show that oxidative stress is a main apoptosis stimulating factor in different diseases including cardiovascular diseases and ROS induces apoptosis. Hence, this process may be inhibited by abundant natural antioxidants. A summary of possible pesticides exposure routes and mechanisms of natural products against pesticidesinduced cardiotoxicity is presented in Figure 3.

\section{Herbicides-Induced Cardiotoxicity}

Atrazine is an extensively used herbicide of the triazine class. Due to its soil leaching properties, atrazine is easy to be leached by rainwater, irrigation water to deeper soil, or enters rivers and lakes with surface runoff. In addition, atrazine remains in surface water and groundwater for a long time and is difficult to degrade, thus causing serious pollution to the ecological environment. Exposure to atrazine can cause health risks to humans and other animal species. As early as the 1990s, atrazine and its anabolic metabolites (for example, atrazine-decrystallized-desubstituent) have been detected in heart tissue (du Preez and van Vuren, 1992) and cause cardiovascular disease during poisoning intoxication (Chan et al., 2007; Li et al., 2018). Curcumin is a polyphenol compound isolated from Curcuma longa L. (turmeric), which has been widely used in the food industry as a common natural pigment for a long time. Curcumin's powerful anti-inflammatory and antioxidant effects, coupled with its ability to improve endothelial function, can reduce the risk of heart disease (Kocaadam and Şanlier, 2017). Keshk et al. concluded that the administration of curcumin $(400 \mathrm{mg} / \mathrm{kg} \mathrm{bm}, 21$ days $)$ can improve the cardiotoxicity induced by ATR via regulating redox state, mitochondrial function and caspase-3 expression (Keshk et al., 2014). Lycopene, a carotenoid existed in plant foods, has a higher content in ripe red plant fruits, especially in tomatoes, carrots, watermelons. With robust free radical scavenging and antioxidant ability, lycopene has attracted considerable attention as a potential chemopreventive agent against diseases such as CVD (Grabowska et al., 2019). Atrazine induced cardiotoxicity by regulating the activity of cardiac ATPase and the transcription of its subunits, thereby triggering ion disorders, while supplemented lycopene $(5 \mathrm{mg} / \mathrm{kg}$ 


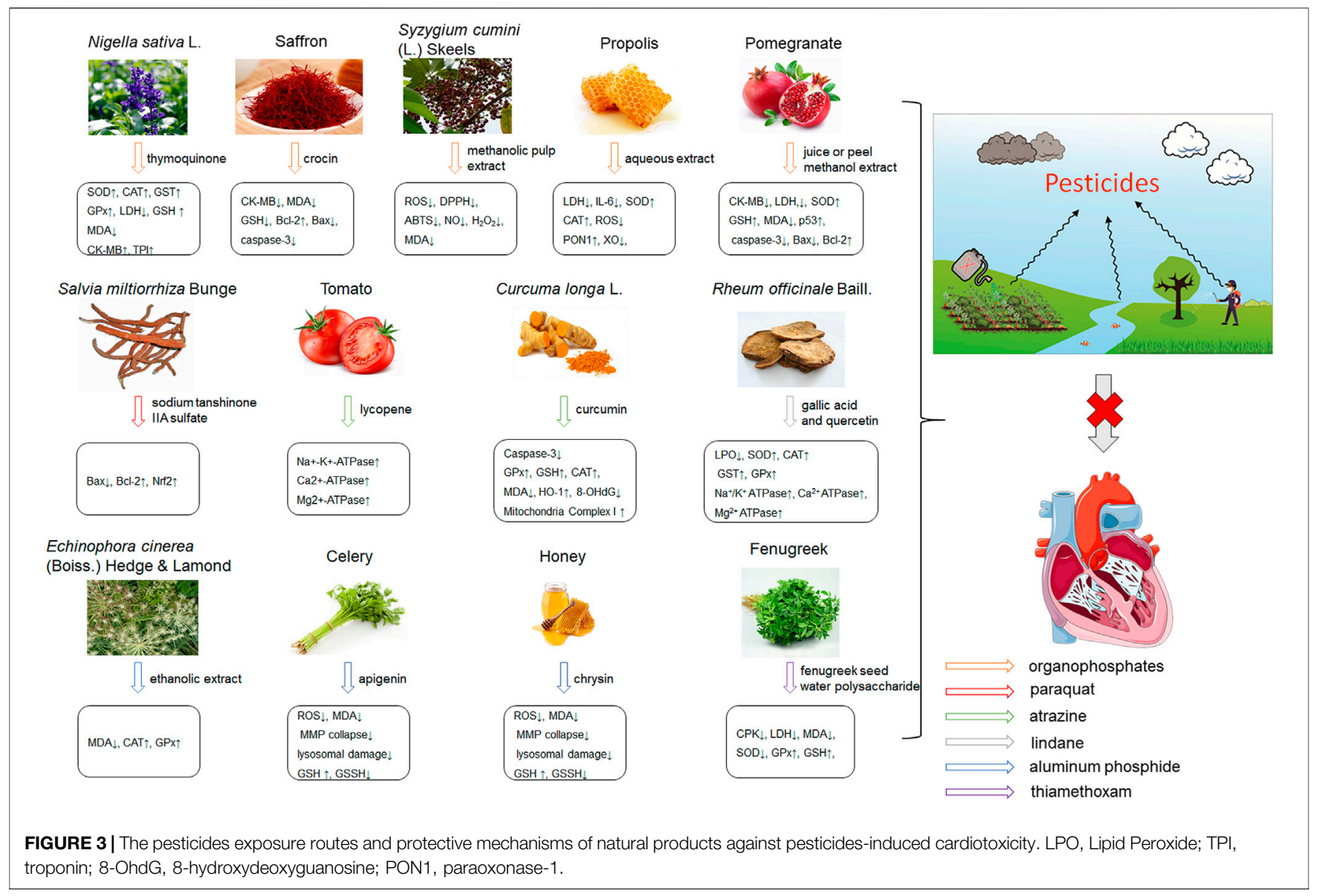

bm, 21 days) in mice significantly counteracted atrazine-induced cardiotoxicity by regulating ATPase activity and subunit transcription. Therefore, lycopene shows a significant chemopreventive potential for atrazine-induced cardiotoxicity (Lin et al., 2016).

Paraquat is a quick-acting contact-killing herbicide which has been widely used due to its good weeding effect and low environmental pollution. However, in the past few decades, there have been many deaths of paraquat, mainly due to accidental or voluntary ingestion. Once ingested orally, paraquat has extremely strong toxic effects on multiple organs, causing lung, heart, liver and kidney failure and even death (Dinis-Oliveira et al., 2008; Gawarammana and Buckley, 2011; Zhang et al., 2018). Because no effective treatment has been developed so far, the paraquat poisoning incident is extremely distressing but powerless. Medicinal plants provide abundant resources for screening new therapeutic agents. Tanshinone IIA, one of the active components of Danshen (Salvia miltiorrhiza Bunge), has a wide range of powerful pharmacological effects, including antioxidant and anti-inflammatory effects (Feng et al., 2019). As a clinical formulation of Tanshinone IIA, sodium tanshinone IIA sulfate is commonly used to improve myocardial blood and oxygen supply in clinical practice. According to Zhang et al,, sodium tanshinone IIA sulfate therapeutically inhibits paraquat-induced myocardial cell apoptosis in rats via the enhancement of Bcl-2, the inhibition of Bax and modulating the Nrf2 pathway (Zhang et al., 2019).

\section{Insecticide-Induced Cardiotoxicity Organophosphates-Induced Cardiotoxicity}

Approximately $40 \%$ of all pesticides commercially produced and used are organophosphates, which are widely used in the agricultural field (Kaushal et al., 2021). Organophosphates induced toxicity is mainly via inhibition of carboxyl ester hydrolases, particularly acetylcholinesterase, and it is reported that the most significant side effect of this mode of action is the oxidative stress induced in the myocardial tissue (Georgiadis et al., 2018).

Malathion is a low-toxic organophosphorus pesticide. Atale et al. (2014) conducted cell proliferation studies in malathiontreated cells, using various natural and synthetic antioxidants, including butylated hydroxyltoluene, trolox, quercetin, (-)-epicatechin, ascorbic acid, curcumin, and gallic acid. Among all the antioxidants mentioned above, gallic acid showed the most significant protection against oxidative stress. Syzygium cumini (L.) Skeels is a traditional medicinal plant with various bioactive compounds distributed in all parts of the plant (Chhikara et al., 2018). S. cumini methanolic pulp extract, rich in gallic acid, was taken to study its effect on malathion-induced toxicity. The result showed that with the treatment with S. cumini 
methanolic pulp extract, malathion-induced morphological changes, ROS levels and nuclear deformities have decreased. Increment in collagen content could also be clearly observed. Hence, S. cumini methanolic pulp extract could ameliorate the oxidative stress in $\mathrm{H} 9 \mathrm{c} 2$ cells caused by malathion, which indicates that it has antioxidant properties and protective effects on malathion-induced cardiotoxicity.

Chlorpyrifos is a moderately toxic organophosphate insecticide, which was once banned from being used on vegetables due to excessive residues. The acute toxicity of chlorpyrifos mostly affects the nervous system and cardiovascular system (Cunha et al., 2018; Shou et al., 2019). It is said that chlorpyrifos poisoning induces heart tissue to produce abundant free radicals, making it particularly vulnerable to oxidative stress and peroxidative damage. As a traditional Chinese medicine, saffron (Crocus sativus L.) has been used for centuries around the world, known for its extensive pharmacological activities including antioxidant. The efficacy of saffron is mainly attributed to the presence of crocin (Javandoost et al., 2017), which can effectively prevent cardiotoxicity, hepatotoxicity and DNA damage (Mohammadi et al., 2018). Studies have shown that crocin can improve the histopathological changes caused by doxorubicin (Razmaraii et al., 2016), and attenuated the cardiotoxicity induced by diazinon (Razavi et al., 2013). Khalaf et al. proved that the cardiotoxicity of chlorpyrifos is mainly due to oxidative stress and crocin can alleviate this toxic effect by its antioxidant property (Khalaf and El-Mansy, 2019). Propolis, a colloidal natural product with a variety of pharmacological activities, has been widely used in medicine, health food, cosmetics and other fields. Propolis contains a lot of flavonoids and polyphenols which correlates with its physiological activity, such as antiinflammatory, antioxidant and immunomodulatory activities (Zabaiou et al., 2017). A recent study has shown that propolis intake may reduce the risk of cardiovascular diseases caused by chlorpyrifos exposure by the improvement of PON1 and XO mRNA genes regulation leading to the accumulation of the cellular enzymatic and/or non-enzymatic antioxidants (Ibrahim et al., 2019). Pomegranate (Punica granatum L.) is a common fruit rich in polyphenols such as ellagic acid and ellagitannin. Administration of either its juice or peel methanol extract has shown protective potential against chlorpyrifos-induced cardiotoxicity potentially via its antioxidant, antiapoptotic and membrane stabilizing properties (El-Wakf et al., 2018).

Diazinon is a moderately toxic, novel, broad-spectrum organophosphorus pesticide. Subchronic exposure to diazinon can induce mitochondrial-mediated apoptosis in rat cardiac tissue. The above-mentioned crocin can also play a protective role in diazinon-induced cardiotoxicity by reducing lipid peroxidation and alleviating apoptosis (Razavi et al., 2013). Nigella sativa L. is a member of family Ranunculaceae Juss. Its seeds, the main source of the active ingredients of the plant, have long been used as a treatment for various pathological diseases in the Middle East and Far East (Ali and Blunden, 2003). As a strong antioxidant and anti-inflammatory agent, thymoquinone has proved to be the most bioactive ingredient in $N$. sativa seeds.
Sub-acute exposure to diazinon significantly induces oxidative damage and inhibits the antioxidant defense system. Thymoquinone supplement could inhibit diazinon-induced cardiotoxicity and improved cholinesterase activity in rats via the mechanism of free radical scavenging (Danaei et al., 2019).

\section{Other Insecticide-Induced Cardiotoxicity}

Aluminum phosphide (ALP) is one of the most widely used metal phosphides, often used as a solid fumigant to exterminate pests (Hosseini et al., 2020). Once ALP is exposed to water or acid, it will release highly toxic phosphine gas (Kariman et al., 2012). Hence, whether it is taken orally or inhaled phosphine gas, it may cause severe poisoning or even death. Due to the extreme toxicity of ALP, more than $70 \%$ of people exposed die from its detrimental effects on various organs of the body and their main cause is cardiotoxicity. ALP-induced cardiovascular disturbances include refractory hypotension, dysrhythmia, and congestive heart failure (Asghari et al., 2017b). The primary mechanism of aluminum phosphide poisoning is the inhibitory effect of phosphine on cytochrome C oxidase (Nath et al., 2011; Mehrpour et al., 2019). Other mechanisms refer to oxidative stress, calcium and magnesium complexation, and damage to the electron transport chain (Nath et al., 2011; Anand et al., 2013). Increasing studies have shown that the active compounds found in plants are effective against chemical and druginduced cardiotoxicity. Chrysin is a flavonoid compound with a wide range of pharmacological activities. Recently, a study in animal model showed the protective effect of chrysin against doxorubicin-induced cardiomyopathy (Mantawy et al., 2017). The protective effect of chrysin on doxorubicin-induced cardiotoxicity is exerted via the mitochondrial apoptosis pathway and the inhibition of oxidative stress (Samarghandian et al., 2017). Similarly, Khezri et al. found that treatment with chrysin significantly reduced the formation of ROS, lysosomal damage, mitochondrial damage and lipid peroxidation induced by ALP (Khezri et al., 2020). A recent study conducted by Jahedsani et al. showed that apigenin also has the same protective effect as chrysin against ALP-induced myocardial damage (Mahajan et al., 2017). Since these studies were performed in primary rat cardiomyocytes or isolated mitochondria, further studies are needed to verify the cardioprotective effects by animal trials and clinical trials on humans. Echinophora cinerea (Boiss.) Hedge \& Lamond is a native Iranian plant, whose erial parts are often used as food seasoning in cheese and yogurt. Research suggests that a flavonoid glucoside extracted from $E$. cinerea showed cytoprotective effect against oxidative stress induced by hydrogen peroxide in PC12 cells (Shokoohinia et al., 2015). Haydari et al. demonstrated that administration of the E. cinerea extract can improve bradycardia, hypotension, and conduction disturbances of the rats heart caused by ALP poisoning (Haydari et al., 2020). It can also increase the level of antioxidant enzymes and protect human body from ALPinduced oxidative damage which shows a dose-dependent characteristic to a certain extent.

Lindane, an artificial chlorinated hydrocarbon pesticide which was first introduced as a scabicide for human use in the 1950s (Solomon et al., 1977), was once widely used for agricultural and 
public health pest control. Its persistence in the environment, high toxicity to mammals, and resistance to biodegradation have led many developed and developing countries to ban or restrict its use. As early as 2005, it has reported that lindane could cause oxidative stress, lipid peroxidation and changes in the levels of enzymatic antioxidants in the rat heart (Ananya et al., 2005). Padma et al. found that oral administration of gallic acid or quercetin protects against lindane-induced myocardial damage, possibly via maintaining the level of endogenous antioxidant enzymes and membrane-bound ATPase activity, and inhibiting lipid peroxidation (Vijaya Padma et al., 2013).

Thiamethoxam, the second-generation nicotinic insecticide, is widely used to protect cotton, sorghum and other crops from being attacked by insects and pests. Due to its slow metabolism in plants and soil and high solubility in water, thiamethoxam poses a major risk to aquatic ecosystems and human health. Feki et al. used $\mathrm{H} 9 \mathrm{c} 2$ cardiomyoblastes and in vivo using Wistar rat model to confirm the toxic effect of thiamethoxam on the heart for the first time. Fenugreek (Trigonella foenum-graecum L.), an annual herb of the family Fabaceae Lindl., is considered to be one of the oldest medicinal plants. Feki et al. extracted a polysaccharide from fenugreek seeds, called fenugreek seed water polysaccharide. Administration of this polysaccharide to thiamethoxam-treated rats shows a strong protective effect on the oxidative stress of the heart, which is manifested in the significant improvement of enzymatic and non-enzymatic antioxidants and the restoration of histopathological changes in the heart tissue (Feki et al., 2019). Fenugreek seed water polysaccharide owns a great cardioprotective potential, but its specific mechanism needs to be further elucidated.

Throughout these studies mentioned above, we found that most studies on the protective effects of natural products in pesticides-induced cardiotoxicity were carried out in animals. However, in-vitro studies are indispensable for in-depth study of the action mechanism and complex signal networks of natural products. Due to differences in the metabolism and physiology of animals and humans, the animal models used cannot fully simulate the development of human diseases. Therefore, further clinical trials are needed to evaluate effectiveness and safety of natural products.

\section{FUTURE NEEDS AND PRIORITIES}

People are exposed to environmental toxins in various ways unconsciously. Once the environmental toxins enter the human body, they are difficult to eliminate and the content in the body slowly accumulates over time, eventually reaching the cumulative dose, damaging tissues and even organs. Although few specific environmental toxins directly target the heart, their more or less toxic effects on the heart cannot be ignored. Regrettably, despite the existence of common cardioprotective drugs in the pharmaceutical market, there is a lack of specific targeted treatment. Cardiotoxicity is still a major medical problem. Therefore, there is an urgent need to study and determine the potential molecular mechanisms and signal transduction pathways that antagonize environmental toxins-induced cardiotoxicity. Early studies mostly revealed the important role of oxidative stress, and the corresponding antagonistic method is to remove ROS. As a recent research report, the strong antioxidant resveratrol significantly inhibits the production of ROS, thereby inhibiting oxidative stress, and thus plays a protective effect on PM2.5-induced heart defects in zebrafish embryos (Ren et al., 2020). Although this method has been successful in cells and experimental animal models to some extent, the use of ROS scavengers (such as N-Acetyl-Lcysteine and L-carnitine) does not seem to be popular in the clinical practice, which indicated that oxidative stress is not the only cause of cardiotoxicity. Growing studies provided potent evidence that besides oxidative stress, environmental toxinsinduced cardiotoxicity can also be affected by inflammation and changes in cardiac ion channels and ion disorders. Most natural products have multiple "targets" and may affect more than one signaling pathway. The development of multi-site targeted natural products and multi-component traditional Chinese herbal medicine can be used for the treatment of cardiotoxicity induced by environmental toxins.

The occurrence and development of cardiotoxicity are accompanied by the damage and even the death of cardiomyocytes, indicating that cardiomyocytes death may be the main cause of cardiotoxicity. The mechanism of environmental toxins-induced cardiotoxicity is sophisticated, but existing research point out that its ultimate result is cardiomyocyte apoptosis. In addition to apoptosis, a common form of cell death, drug-induced cardiomyocytes death forms also include autophagy, necrosis and other regulated forms, such as necroptosis, pryoptosis, and ferroptosis (Ma et al., 2020). Hence, whether there are other forms of cell death in cardiotoxicity induced by environmental toxins remains to be further studied.

As mentioned above, it can be found that the active ingredients in daily food, such as lycopene in tomatoes and ellagic acid in nuts and fruits, have a beneficial effect on the cardiotoxicity induced by environmental toxins, which suggests that people, especially workers who are occupationally exposed to these environmental toxins may be able to reduce the risk of poisoning by consciously increasing their intake of these foods. Epidemiological studies are needed for further confirmed.

Although in pre-clinical studies, natural products have made significant progress in preventing cardiotoxicity caused by environmental toxins, they have not yet been converted into clinical use. The main hindrance to the development of natural products-based cardioprotective adjuvants attributes to the low bioavailability of natural products (Novelle et al., 2015). Actually, natural products must be supplied in sufficient doses to enter the systemic circulation in the form of their natural structures or metabolites and reach target tissues to exert biological activity. As typical natural products with strong antioxidant capacity, polyphenols have effective protective effects on cardiotoxicity induced by environmental toxins. The antioxidant activity of polyphenols depends on their ability to scavenge free radicals, donate hydrogen atoms or electrons, or chelate metal cations, and the structure is a key determinant of their free radical scavenging and metal chelating activity (Yordi et al., 2012). However, due to 
TABLE 1 | Protective effect of natural products against environmental toxins-induced cardiotoxicity.

\begin{tabular}{|c|c|c|c|c|c|}
\hline $\begin{array}{l}\text { Environmental- } \\
\text { toxins }\end{array}$ & Natural products & $\begin{array}{l}\text { Structure or } \\
\text { effective component }\end{array}$ & Model & Effect & Ref \\
\hline \multirow[t]{4}{*}{ Cadmium } & Quercetin & & Male albino rats & $\begin{array}{l}\text { Attenuated oxidative stress mediated } \\
\text { cardiotoxicity and dyslipidemia }\end{array}$ & $\begin{array}{l}\text { Milton Prabu } \\
\text { et al. (2013) }\end{array}$ \\
\hline & $\begin{array}{l}\text { Grape seed } \\
\text { proanthocyanidins }\end{array}$ & & Male Wistar rats & $\begin{array}{l}\text { Inhibiting the membrane disturbances in } \\
\text { cardiomyocytes, apoptotic pathway and } \\
\text { inflammation }\end{array}$ & $\begin{array}{l}\text { Nazimabashir } \\
\text { et al. (2015) }\end{array}$ \\
\hline & $\begin{array}{l}\text { Tinospora cordifolia } \\
\text { (Willd.) Hook.f. \& } \\
\text { Thomson }\end{array}$ & Stem hydroalcoholic extract & Male Wistar rats & $\begin{array}{l}\text { Inhibited oxidative damage, reduced heart } \\
\text { histological alterations and decreased the } \\
\text { activities of membrane bound ATPases }\end{array}$ & $\begin{array}{l}\text { Priya et al. } \\
\text { (2017) }\end{array}$ \\
\hline & Allium cepa L. & Onion bulbs raw juice & Male SD rats & $\begin{array}{l}\text { Reduced oxidative stress, histological } \\
\text { damage and apoptosis }\end{array}$ & $\begin{array}{l}\text { Alpsoy et al. } \\
(2014)\end{array}$ \\
\hline Arsenic & Arjunolic acid & & $\begin{array}{l}\text { Male Swiss albino } \\
\text { mice }\end{array}$ & $\begin{array}{l}\text { Prevent cardiac oxidative impairment and } \\
\text { maintain the normal ultra structure }\end{array}$ & $\begin{array}{l}\text { Manna et al. } \\
(2008)\end{array}$ \\
\hline
\end{tabular}

(-)-Epigallocatechin3-gallate

Quercetin

Silibinin

p-Coumaric acid<smiles>O=C(O[C@H]1Cc2c(O)cc(O)cc2O[C@@H]1c1cc(O)c(O)c(O)c1)c1ccc(O)c(O)c1</smiles>

Male SD rats; H9c2 cells<smiles>O=c1c(O)c(-c2ccc(O)c(O)c2)oc2cc(O)cc(O)c12</smiles>

Male SD rats<smiles>COc1cc(C2Cc3cc(-c4oc5cc(O)cc(O)c5c(=O)c4O)ccc3OC2CO)ccc1O</smiles>

Male albino Wistar rats

Male Wistar albino rats

Male Swiss albino mice; H9c2 cells Male Wistar rats

Trichosanthes dioica

Roxb.

Corchorus olitorius L.<smiles>O=C(O)/C=C/c1ccc(O)cc1</smiles><smiles>CCCCCCCCC=CCCCCCCCC(=O)O</smiles><smiles>O=c1oc2c(O)c(O)cc3c(=O)oc4c(O)c(O)cc1c4c23</smiles>

Aqueous extraction

Dry water ethanol extract
Male Wistar albino rats

Male Wistar albino rats
Attenuated myocardial injury, oxidative damage and myocardial apoptosis

Ameliorated oxido-nitrosative stress and myocardial injury

Mukherjee et al (2017)

Eliminated myocardial damages, facilitated the restoration of antioxidant status and normal histological architecture of cardiac tissue

Reduced myocardial oxidative stress and ameliorated cardiac damage

Prasanna et al. (2013)

Attenuated cardiac hypertrophy

Samanta et al. (2020)

Prevented histopathological alterations and reduced oxidative stress

Goudarzi et al. (2018)
Ameliorated myocardial injury and reduced DNA fragmentation
Bhattacharya et al. (2014) Das et al. (2010)

(Continued on following page) 
TABLE 1 | (Continued) Protective effect of natural products against environmental toxins-induced cardiotoxicity.

Environmental- Natural products toxins
Structure or effective component

\begin{tabular}{|c|c|c|c|c|c|}
\hline & Naringin & $\gamma$ & Male SD rats & $\begin{array}{l}\text { Reduced oxidative impairment and } \\
\text { prevented hyperlipidemia and DNA } \\
\text { fragmentation. } \\
\text { Reduced ROS production and oxidative } \\
\text { stress, scavenged free radicals, inhibited } \\
\text { apoptosis and restored the respiratory chain } \\
\text { Complexes }\end{array}$ & Adil et al. (2016) \\
\hline & Hesperidin & & Male SD rats & $\begin{array}{l}\text { Reduced oxidative stress and apoptosis, } \\
\text { increased antioxidant enzyme activities, and } \\
\text { prevented inflamma-tion }\end{array}$ & $\begin{array}{l}\text { Kuzu et al. } \\
(2021)\end{array}$ \\
\hline \multirow[t]{12}{*}{ Pesticides } & Curcumin & & Male albino rats & $\begin{array}{l}\text { Ameliorated disturbed redox status and } \\
\text { mitochondrial dysfunction }\end{array}$ & $\begin{array}{l}\text { Keshk et al. } \\
(2014)\end{array}$ \\
\hline & Lycopene & & Male KunMing mice & $\begin{array}{l}\text { Ameliorated cardiomyocyte ATPase function } \\
\text { and ionic levels }\end{array}$ & Lin et al. (2016) \\
\hline & $\begin{array}{l}\text { Sodium tanshinone } \\
\text { IIA sulfate }\end{array}$ & & $\mathrm{SD}$ rats & $\begin{array}{l}\text { Inhibited apoptosis, myocardial damage and } \\
\text { failure }\end{array}$ & $\begin{array}{l}\text { Zhang et al. } \\
\text { (2019) }\end{array}$ \\
\hline & $\begin{array}{l}\text { Syzygium cumini }(L .) \\
\text { Skeels } \\
\text { Crocin }\end{array}$ & Methanolic pulp extract & $\begin{array}{l}\text { H9c2 cells } \\
\text { Male albino rats/ } \\
\text { male Wistar rats }\end{array}$ & $\begin{array}{l}\text { Suppress changes in cell morphology, ROS } \\
\text { production and ECM remodeling } \\
\text { Alleviated oxidative stress and ameliorated } \\
\text { myocardial injury/reduced lipid peroxidation } \\
\text { and alleviated apoptosis }\end{array}$ & $\begin{array}{l}\text { Atale et al. } \\
\text { (2014) } \\
\text { (Razavi et al., } \\
\text { 2013; Khalaf } \\
\text { and El-Mansy, } \\
\text { 2019) }\end{array}$ \\
\hline & Propolis & Aqueous extract & Male albino rats & $\begin{array}{l}\text { Restored antioxidant defense system } \\
\text { disorder }\end{array}$ & $\begin{array}{l}\text { Ibrahim et al. } \\
\text { (2019) }\end{array}$ \\
\hline & $\begin{array}{l}\text { Pomegranate (Punica } \\
\text { granatum L.) }\end{array}$ & Juice or peel methanol extract & Male albino rats & Attenuated myocardial injury and apoptosis & $\begin{array}{l}\text { El-Wakf et al. } \\
(2018)\end{array}$ \\
\hline & Thymoquinone & & $\begin{array}{l}\text { Rats (detailed strain } \\
\text { is not mentioned) }\end{array}$ & $\begin{array}{l}\text { Decreased cardiotoxicity and improved } \\
\text { cholinesterase activity }\end{array}$ & $\begin{array}{l}\text { Danaei et al. } \\
\text { (2019) }\end{array}$ \\
\hline & Chrysin & & $\begin{array}{l}\text { Primary male Wistar } \\
\text { rats } \\
\text { cardiomyocytes; } \\
\text { isolated } \\
\text { mitochondria }\end{array}$ & $\begin{array}{l}\text { Ameliorated oxidative stress and } \\
\text { mitochondrial damages }\end{array}$ & $\begin{array}{l}\text { Khezri et al. } \\
\text { (2020) }\end{array}$ \\
\hline & Apigenin & $\mathrm{HO}$ & $\begin{array}{l}\text { Primary male Wistar } \\
\text { rats cardiomyocytes }\end{array}$ & $\begin{array}{l}\text { Decreased cytotoxicity, oxidative, lysosomal } \\
\text { and mitochondrial damages }\end{array}$ & $\begin{array}{l}\text { Mahajan et al. } \\
(2017)\end{array}$ \\
\hline & $\begin{array}{l}\text { Echinophora cinerea } \\
\text { (Boiss.) Hedge \& }\end{array}$ & Ethanolic extract & Male wistar rats & $\begin{array}{l}\text { Improve bradycardia, hypotension, and } \\
\text { conduction disturbances }\end{array}$ & $\begin{array}{l}\text { Haydari et al. } \\
\text { (2020) }\end{array}$ \\
\hline & Gallic acid & $\mathrm{OH}$ & $\begin{array}{l}\text { Male albino Wistar } \\
\text { rats }\end{array}$ & $\begin{array}{l}\text { Improved the status of enzymatic and non- } \\
\text { enzymatic antioxidants and ameliorated } \\
\text { myocardial damage }\end{array}$ & $\begin{array}{l}\text { Vijaya Padma } \\
\text { et al. (2013) }\end{array}$ \\
\hline & $\begin{array}{l}\text { Fenugreek (Trigonella } \\
\text { foenum-graecum L.) }\end{array}$ & $\begin{array}{l}\text { a polysaccharide extracted from } \\
\text { fenugreek seeds }\end{array}$ & $\begin{array}{l}\text { Male Wistar rats; } \\
\text { H9c2 cells }\end{array}$ & $\begin{array}{l}\text { Alleviated heart oxidative damage and } \\
\text { genotoxicity }\end{array}$ & Feki et al. (2019) \\
\hline
\end{tabular}


low bioavailability and kinetic limitations, the direct antioxidant activity of polyphenols seems to be insufficient in the body. As Visioli et al. reported, the concentrations of polyphenols used in in-vitro studies usually range from $\mu \mathrm{mol} / \mathrm{L}$ to $\mathrm{mmol} / \mathrm{L}$, while plasma metabolite concentrations rarely exceed nmol/L after normal dietary intake (Visioli et al., 2011). Although polyphenols have been shown to have indirect antioxidant capacity by regulating gene expression and endogenous antioxidant enzyme defense systems as described in our review, it is limited. Therefore, strategies such as structural modification of natural products and changing dosage forms are needed to improve the bioavailability of natural products.

Environmental toxins-induced cardiotoxicity models are mostly established on animals, primary cultured cells or cell lines. A suitable experimental model that simulates the physiology of the human heart is needed. Several natural products have been shown to have cardioprotective effects on environmental toxins-induced cardiotoxicity both in vitro and in vivo, but they are not thorough enough, and mechanisms of action have not been fully elucidated. Moreover, most of the existing research focuses on oxidation, inflammation and apoptosis, and more attention should be paid to the complex signal network, which is the core of cardiomyocyte survival and dysfunction (Ghigo et al., 2016). However, we have to admit that in-vivo and in-vitro studies have certain limitations. One of the disadvantages of in-vitro studies is that the effective dose used is much higher than concentration that can be achieved in humans. In addition, in-vitro studies use prototype compounds of natural products, rarely involving their active metabolites. As for in-vivo studies, due to differences in metabolism, genomics and physiology, the animal models used do not fully mimic the development of human diseases. The results obtained in in-vivo studies need to be transformed into humans. Collectively, a large number of compounds are proven to be effective in vivo and in vitro studies, but most of them cannot be converted into evidence for therapeutic benefits (Heinrich et al., 2020). From the discovery of new agents to the conversion into clinical use,

\section{REFERENCES}

Adil, M., Kandhare, A. D., Ghosh, P., and Bodhankar, S. L. (2016). Sodium Arsenite-Induced Myocardial Bruise in Rats: Ameliorative Effect of Naringin via TGF- $\beta /$ Smad and Nrf/HO Pathways. Chemico-Biological Interactions 253, 66-77. doi:10.1016/j.cbi.2016.05.015

Adil, M., Kandhare, A. D., Visnagri, A., and Bodhankar, S. L. (2015). Naringin Ameliorates Sodium Arsenite-Induced Renal and Hepatic Toxicity in Rats: Decisive Role of KIM-1, Caspase-3, TGF- $\beta$, and TNF- $\alpha$. Ren. Fail. 37 (8), 1396-1407. doi:10.3109/0886022x.2015.1074462

Al-Mallah, M. H., Sakr, S., and Al-Qunaibet, A. (2018). Cardiorespiratory Fitness and Cardiovascular Disease Prevention: an Update. Curr. Atheroscler. Rep. 20 (1), 1. doi:10.1007/s11883-018-0711-4

Alamolhodaei, N. S., Shirani, K., and Karimi, G. (2015). Arsenic Cardiotoxicity: An Overview. Environ. Toxicol. Pharmacol. 40 (3), 1005-1014. doi:10.1016/ j.etap.2015.08.030

Ali, B. H., and Blunden, G. (2003). Pharmacological and Toxicological Properties of Nigella Sativa. Phytother. Res. 17 (4), 299-305. doi:10.1002/ptr.1309

Ali, S., Awan, Z., Mumtaz, S., Shakir, H. A., Ahmad, F., Ulhaq, M., et al. (2020). Cardiac Toxicity of Heavy Metals (Cadmium and Mercury) and Pharmacological Intervention by Vitamin C in Rabbits. Environ. Sci. Pollut. Res. 27 (23), 29266-29279. doi:10.1007/s11356-020-09011-9 there is still a long way to go to develop natural products to combat cardiotoxicity induced by environmental toxins.

\section{CONCLUSION}

When evaluating the toxicity of environmental toxins, cardiotoxicity is an important consideration because myocardial damage can be irreversible and fatal. Mechanism of environmental toxins-induced cardiotoxicity is sophisticated and involves multiple targets and pathways, making it difficult to take corresponding intervention measures. This article reviews the mechanism of environmental toxins-induced cardiotoxicity and summarizes the protective effects of natural products on environmental toxins-induced cardiotoxicity. A list of valuable natural products has been mentioned in Table $\mathbf{1}$. Medicinal plants can be used as a source of useful novel compounds to develop effective treatments to combat cardiotoxicity in patients exposed to environmental toxins.

\section{AUTHOR CONTRIBUTIONS}

YY and SW wrote the manuscript. BZ and WL revised the manuscript. All authors read and approved the final version of the manuscript for publication.

\section{FUNDING}

This work was supported by grants from the National Natural Scientific Foundation of China (Nos. 81703518 and 81973406), the Hunan Provincial Natural Scientific Foundation (Nos. 2019JJ50849 and 2020JJ4823), Scientific Research Project of Hunan Provincial Health and Family Planning Commission (No. 202113050843), and the Bethune Quest-Pharmaceutical Research Capacity Building Project (No. B-19-H-20200622).

Alpsoy, S., Kanter, M., Aktas, C., Erboga, M., Akyuz, A., Akkoyun, D. C., et al. (2014). Protective Effects of Onion Extract on Cadmium-Induced Oxidative Stress, Histological Damage, and Apoptosis in Rat Heart. Biol. Trace Elem. Res. 159 (1-3), 297-303. doi:10.1007/s12011-014-9968-9

Anand, R., Binukumar, B. K., and Gill, K. D. (2011). Aluminum Phosphide Poisoning: an Unsolved riddle. J. Appl. Toxicol. 31 (6), 499-505. doi:10.1002/jat.1692

Anand, R., Sharma, D. R., Verma, D., Bhalla, A., Gill, K. D., and Singh, S. (2013). Mitochondrial Electron Transport Chain Complexes, Catalase and Markers of Oxidative Stress in Platelets of Patients with Severe Aluminum Phosphide Poisoning. Hum. Exp. Toxicol. 32 (8), 807-816. doi:10.1177/0960327112468909

Ananya, R., Subeena, S., Kumar, D. A., Kumar, D. T., and Kumar, M. S. (2005). Oxidative Stress and Histopathological Changes in the Heart Following Oral Lindane (Gamma Hexachlorohexane) Administration in Rats. Med. Sci. Monit. 11 (9), Br325-9.

Asghari, M. H., Abdollahi, M., de Oliveira, M. R., and Nabavi, S. M. (2017a). A Review of the Protective Role of Melatonin during Phosphine-Induced Cardiotoxicity: Focus on Mitochondrial Dysfunction, Oxidative Stress and Apoptosis. J. Pharm. Pharmacol. 69 (3), 236-243. doi:10.1111/jphp.12682

Asghari, M. H., Moloudizargari, M., Baeeri, M., Baghaei, A., Rahimifard, M., Solgi, R., et al. (2017b). On the Mechanisms of Melatonin in protection of Aluminum Phosphide Cardiotoxicity. Arch. Toxicol. 91 (9), 3109-3120. doi:10.1007/ s00204-017-1998-6 
Atale, N., Gupta, K., and Rani, V. (2014). Protective Effect of Syzygium Cumini against Pesticide-Induced Cardiotoxicity. Environ. Sci. Pollut. Res. 21 (13), 7956-7972. doi:10.1007/s11356-014-2684-3

Bagchi, D., Bagchi, M., Stohs, S. J., Ray, S. D., Sen, C. K., and Preuss, H. G. (2002). Cellular protection with Proanthocyanidins Derived from Grape Seeds. Ann. N. Y Acad. Sci. 957, 260-270. doi:10.1111/j.1749-6632.2002.tb02922.x

Baghaei, A., Solgi, R., Jafari, A., Abdolghaffari, A. H., Golaghaei, A., Asghari, M. H., et al. (2016). Molecular and Biochemical Evidence on the protection of Cardiomyocytes from Phosphine-Induced Oxidative Stress, Mitochondrial Dysfunction and Apoptosis by Acetyl-L-Carnitine. Environ. Toxicol. Pharmacol. 42, 30-37. doi:10.1016/j.etap.2015.12.019

Banerjee, B. D., Seth, V., Bhattacharya, A., Pasha, S. T., and Chakraborty, A. K. (1999). Biochemical Effects of Some Pesticides on Lipid Peroxidation and FreeRadical Scavengers. Toxicol. Lett. 107 (1-3), 33-47. doi:10.1016/s0378-4274(99) 00029-6

Bhattacharya, S., Das, S. K., and Haldar, P. K. (2014). Arsenic Induced Myocardial Toxicity in Rats: Alleviative Effect ofTrichosanthes dioicaFruit. J. Dietary Supplements 11 (3), 248-261. doi:10.3109/19390211.2014.937044

Bhattacharya, S., and Haldar, P. K. (2012). Protective Role of the TriterpenoidEnriched Extract of Trichosanthes Dioicaroot against Experimentally Induced Pain and Inflammation in Rodents. Nat. Product. Res. 26 (24), 2348-2352. doi:10.1080/14786419.2012.656111

Bhattacharya, S., and Haldar, P. K. (2013). Trichosanthes Dioica Root Alleviates Arsenic Induced Myocardial Toxicity in Rats. J. Environ. Pathol. Toxicol. Oncol. 32 (3), 251-261. doi:10.1615/jenvironpatholtoxicoloncol.2013008541

Bhattacharya, S., Prasanna, A., Majumdar, P., Kumar, R. S., and Haldar, P. K. (2011). Antitumor Efficacy and Amelioration of Oxidative Stress byTrichosanthes Dioicaroot against Ehrlich Ascites Carcinoma in Mice. Pharm. Biol. 49 (9), 927-935. doi:10.3109/13880209.2011.557080

Björnsson, E. S., and Hoofnagle, J. H. (2016). Categorization of Drugs Implicated in Causing Liver Injury: Critical Assessment Based on Published Case Reports. Hepatology 63 (2), 590-603. doi:10.1002/hep.28323

Bors, W., Foo, L. Y., Hertkorn, N., Michel, C., and Stettmaier, K. (2001). Chemical Studies of Proanthocyanidins and Hydrolyzable Tannins. Antioxid. Redox Signaling 3 (6), 995-1008. doi:10.1089/152308601317203530

Branca, J. J. V., Morucci, G., and Pacini, A. (2018). Cadmium-induced Neurotoxicity: Still Much Ado. Neural Regen. Res. 13 (11), 1879-1882. doi:10.4103/1673-5374.239434

Casalino, E., Sblano, C., and Landriscina, C. (1997). Enzyme Activity Alteration by Cadmium Administration to Rats: the Possibility of Iron Involvement in Lipid Peroxidation. Arch. Biochem. Biophys. 346 (2), 171-179. doi:10.1006/abbi.1997.0197

Castro, L., Demicheli, V., Tórtora, V., and Radi, R. (2011). Mitochondrial Protein Tyrosine Nitration. Free Radic. Res. 45 (1), 37-52. doi:10.3109/ 10715762.2010.516254

Chakrawarti, L., Agrawal, R., Dang, S., Gupta, S., and Gabrani, R. (2016). Therapeutic Effects of EGCG: a Patent Review. Expert Opin. Ther. Patents 26 (8), 907-916. doi:10.1080/13543776.2016.1203419

Chan, Y.-C., Chang, S.-C., Hsuan, S.-L., Chien, M.-S., Lee, W.-C., Kang, J.-J., et al. (2007). Cardiovascular Effects of Herbicides and Formulated Adjuvants on Isolated Rat Aorta and Heart. Toxicol. Vitro 21 (4), 595-603. doi:10.1016/ j.tiv.2006.12.007

Chen, X., Shan, H., Zhao, J., Hong, Y., Bai, Y., Sun, I., et al. (2010). L-type Calcium Current (ICa,L) and Inward Rectifier Potassium Current (Ik1) Are Involved in QT Prolongation Induced by Arsenic Trioxide in Rat. Cell Physiol Biochem 26 (6), 967-974. doi:10.1159/000324005

Chen, Y.-W., Chou, H.-C., Lin, S.-T., Chen, Y.-H., Chang, Y.-J., Chen, L., et al. (2013). Cardioprotective Effects of Quercetin in Cardiomyocyte under Ischemia/Reperfusion Injury. Evidence-Based Complement. Altern. Med. 2013, 1-16. doi:10.1155/2013/364519

Chhikara, N., Kaur, R., Jaglan, S., Sharma, P., Gat, Y., and Panghal, A. (2018). Bioactive Compounds and Pharmacological and Food Applications ofSyzygium Cumini- a Review. Food Funct. 9 (12), 6096-6115. doi:10.1039 $/ \mathrm{c} 8 \mathrm{fo} 00654 \mathrm{~g}$

Cunha, A. F., Felippe, I. S. A., Ferreira-Junior, N. C., Resstel, L. B. M., Guimarães, D. A. M., Beijamini, V., et al. (2018). Neuroreflex Control of Cardiovascular Function Is Impaired after Acute Poisoning with Chlorpyrifos, an Organophosphorus Insecticide: Possible Short and Long Term Clinical Implications. Toxicology 398-399, 13-22. doi:10.1016/j.tox.2018.02.005
Curigliano, G., Cardinale, D., Dent, S., Criscitiello, C., Aseyev, O., Lenihan, D., et al. (2016). Cardiotoxicity of Anticancer Treatments: Epidemiology, Detection, and Management. CA: A Cancer J. Clinicians 66 (4), 309-325. doi:10.3322/ caac. 21341

Danaei, G. H., Memar, B., Ataee, R., and Karami, M. (2019). Protective Effect of Thymoquinone, the Main Component of Nigella Sativa, against Diazinon Cardio-Toxicity in Rats. Drug Chem. Toxicol. 42 (6), 585-591. doi:10.1080/ 01480545.2018.1454459

Das, A. K., Sahu, R., Dua, T. K., Bag, S., Gangopadhyay, M., Sinha, M. K., et al. (2010). Arsenic-induced Myocardial Injury: Protective Role of Corchorus Olitorius Leaves. Food Chem. Toxicol. 48 (5), 1210-1217. doi:10.1016/ j.fct.2010.02.012

Das, A., Roy, A., Das, R., Bhattacharya, S., and Haldar, P. K. (2016). Naringenin Alleviates Cadmium-Induced Toxicity through the Abrogation of Oxidative Stress in Swiss Albino Mice. J. Environ. Pathol. Toxicol. Oncol. 35 (2), 161-169. doi:10.1615/JEnvironPatholToxicolOncol.2016015892

Dinis-Oliveira, R. J., Duarte, J. A., Sánchez-Navarro, A., Remião, F., Bastos, M. L. and Carvalho, F. (2008). Paraquat Poisonings: Mechanisms of Lung Toxicity, Clinical Features, and Treatment. Crit. Rev. Toxicol. 38 (1), 13-71. doi:10.1080/ 10408440701669959

Doroshow, J. H., Locker, G. Y., and Myers, C. E. (1980). Enzymatic Defenses of the Mouse Heart against Reactive Oxygen Metabolites. J. Clin. Invest. 65 (1), 128-135. doi:10.1172/jci109642

du Preez, H. H., and van Vuren, J. H. J. (1992). Bioconcentration of Atrazine in the Banded tilapia, Tilapia Sparrmanii. Comp. Biochem. Physiol. C: Comp. Pharmacol. 101 (3), 651-655. doi:10.1016/0742-8413(92)90100-1

El-Wakf, A. M., El-Habibi, E. S. M., Barakat, N. M., Attia, A. M., Hussein, A. M., and Ali, I. I. (2018). Cardiovascular Toxic Effects of Chlorpyrifos: A Possible Protective Role for Pomegranate Extracts. J. Clin. Toxicol. 8. 1. doi:10.4172/ 2161-0495.1000374

Everett, C. J., and Frithsen, I. L. (2008). Association of Urinary Cadmium and Myocardial Infarction. Environ. Res. 106 (2), 284-286. doi:10.1016/ j.envres.2007.10.009

Feki, A., Ben Saad, H., Bkhairia, I., Ktari, N., Naifar, M., Boudawara, O., et al. (2019). Cardiotoxicity and Myocardial Infarction-Associated DNA Damage Induced by Thiamethoxam In Vitro and In Vivo: Protective Role ofTrigonella Foenum-Graecumseed-Derived Polysaccharide. Environ. Toxicol. 34 (3), 271-282. doi:10.1002/tox.22682

Feng, F., Cheng, P., Zhang, H., Li, N., Qi, Y., Wang, H., et al. (2019). The Protective Role of Tanshinone IIA in Silicosis Rat Model via TGF- $\beta 1 /$ Smad Signaling Suppression, NOX4 Inhibition and Nrf2/ARE Signaling Activation. Dddt 13, 4275-4290. doi:10.2147/dddt.S230572

Ficker, E., Kuryshev, Y. A., Dennis, A. T., Obejero-Paz, C., Wang, L., Hawryluk, P., et al. (2004). Mechanisms of Arsenic-Induced Prolongation of Cardiac Repolarization. Mol. Pharmacol. 66 (1), 33-44. doi:10.1124/mol.66.1.33

Gawarammana, I. B., and Buckley, N. A. (2011). Medical Management of Paraquat Ingestion. Br. J. Clin. Pharmacol. 72 (5), 745-757. doi:10.1111/j.13652125.2011.04026.x

Georgiadis, N., Tsarouhas, K., Tsitsimpikou, C., Vardavas, A., Rezaee, R., Germanakis, I., et al. (2018). Pesticides and Cardiotoxicity. Where Do We Stand? Toxicol. Appl. Pharmacol. 353, 1-14. doi:10.1016/j.taap.2018.06.004

Ghigo, A., Li, M., and Hirsch, E. (2016). New Signal Transduction Paradigms in Anthracycline-Induced Cardiotoxicity. Biochim. Biophys. Acta (Bba) - Mol. Cel Res. 1863 (7 Pt B), 1916-1925. doi:10.1016/j.bbamcr.2016.01.021

Goudarzi, M., Fatemi, I., Siahpoosh, A., Sezavar, S. H., Mansouri, E., and Mehrzadi, S. (2018). Protective Effect of Ellagic Acid against Sodium Arsenite-Induced Cardio- and Hematotoxicity in Rats. Cardiovasc. Toxicol. 18 (4), 337-345. doi:10.1007/s12012-018-9446-2

Grabowska, M., Wawrzyniak, D., Rolle, K., Chomczyński, P., Oziewicz, S., Jurga, S., et al. (2019). Let Food Be Your Medicine: Nutraceutical Properties of Lycopene. Food Funct. 10 (6), 3090-3102. doi:10.1039/c9fo00580c

Gupta, R., Shukla, R. K., Chandravanshi, L. P., Srivastava, P., Dhuriya, Y. K., Shanker, J., et al. (2017). Protective Role of Quercetin in Cadmium-Induced Cholinergic Dysfunctions in Rat Brain by Modulating Mitochondrial Integrity and MAP Kinase Signaling. Mol. Neurobiol. 54 (6), 4560-4583. doi:10.1007/ s12035-016-9950-y

Haydari, S., Nazari, A., Moghimian, M., Sedighi, M., and Ghaderpour, S. (2020). Cardioprotective Activity of Ethanolic Extract of Echinophora Cinerea against 
Aluminum Phosphide Poisoning in Rats. J. Food Biochem. 44 (8), e13300. doi:10.1111/jfbc.13300

Heinrich, M., Appendino, G., Efferth, T., Fürst, R., Izzo, A. A., Kayser, O., et al. (2020). Best Practice in Research - Overcoming Common Challenges in Phytopharmacological Research. J. Ethnopharmacology 246, 112230. doi:10.1016/j.jep.2019.112230

Hertog, M. G. L., Feskens, E. J. M., Kromhout, D., Hertog, M. G. L., Hollman, P. C. H., Hertog, M. G. L., et al. (1993). Dietary Antioxidant Flavonoids and Risk of Coronary Heart Disease: the Zutphen Elderly Study. The Lancet 342 (8878), 1007-1011. doi:10.1016/0140-6736(93)92876-u

Hosseini, S. F., Forouzesh, M., Maleknia, M., Valiyari, S., Maniati, M., and Samimi, A. (2020). The Molecular Mechanism of Aluminum Phosphide Poisoning in Cardiovascular Disease: Pathophysiology and Diagnostic Approach. Cardiovasc. Toxicol. 20 (5), 454-461. doi:10.1007/s12012-020-09592-4

$\mathrm{Hu}, \mathrm{Y}$, and Cheng, H. (2013). Application of Stochastic Models in Identification and Apportionment of Heavy Metal Pollution Sources in the Surface Soils of a Large-Scale Region. Environ. Sci. Technol. 47 (8), 3752-3760. doi:10.1021/ es304310k

Ibrahim, K. A., Khwanes, S. A., El-Desouky, M. A., and Elhakim, H. K. A. (2019). Propolis Relieves the Cardiotoxicity of Chlorpyrifos in Diabetic Rats via Alleviations of Paraoxonase-1 and Xanthine Oxidase Genes Expression. Pestic. Biochem. Physiol. 159, 127-135. doi:10.1016/j.pestbp.2019.06.006

Jaiswal, A. K. (2004). Nrf2 Signaling in Coordinated Activation of Antioxidant Gene Expression. Free Radic. Biol. Med. 36 (10), 1199-1207. doi:10.1016/ j.freeradbiomed.2004.02.074

Janabi, M., Yamashita, S., Hirano, K.-i., Sakai, N., Hiraoka, H., Matsumoto, K., et al. (2000). Oxidized LDL-Induced NF-Kb Activation and Subsequent Expression of Proinflammatory Genes Are Defective in Monocyte-Derived Macrophages from CD36-Deficient Patients. Arterioscler Thromb. Vasc. Biol. 20 (8), 1953-1960. doi:10.1161/01.atv.20.8.1953

Järup, L., and Åkesson, A. (2009). Current Status of Cadmium as an Environmental Health Problem. Toxicol. Appl. Pharmacol. 238 (3), 201-208. doi:10.1016/ j.taap.2009.04.020

Javandoost, A., Afshari, A., Nikbakht-Jam, I., Khademi, M., Eslami, S., Nosrati, M., et al. (2017). Effect of Crocin, a Carotenoid from Saffron, on Plasma Cholesteryl Ester Transfer Protein and Lipid Profile in Subjects with Metabolic Syndrome: A Double Blind Randomized Clinical Trial. ARYA Atheroscler. 13 (5), 245-252.

Kapoor, R., and Kakkar, P. (2014). Naringenin Accords Hepatoprotection from Streptozotocin Induced Diabetes In Vivo by Modulating Mitochondrial Dysfunction and Apoptotic Signaling cascade. Toxicol. Rep. 1, 569-581. doi:10.1016/j.toxrep.2014.08.002

Kapusta, P., and Sobczyk, Ł. (2015). Effects of Heavy Metal Pollution from Mining and Smelting on Enchytraeid Communities under Different Land Management and Soil Conditions. Sci. Total Environ. 536, 517-526. doi:10.1016/ j.scitotenv.2015.07.086

Kariman, H., Heydari, K., Fakhri, M., Shahrami, A., Dolatabadi, A. A., Mohammadi, H. A., et al. (2012). Aluminium Phosphide Poisoning and Oxidative Stress. J. Med. Toxicol. 8 (3), 281-284. doi:10.1007/s13181-012-0219-1

Kaushal, J., Khatri, M., and Arya, S. K. (2021). A Treatise on Organophosphate Pesticide Pollution: Current Strategies and Advancements in Their Environmental Degradation and Elimination. Ecotoxicology Environ. Saf. 207, 111483. doi:10.1016/j.ecoenv.2020.111483

Keshk, W. A., Soliman, N. A., Abo El-Noor, M. M., Wahdan, A. A., and Shareef, M. M. (2014). Modulatory Effects of Curcumin on Redox Status, Mitochondrial Function, and Caspace-3 Expression during Atrazin-Induced Toxicity. J. Biochem. Mol. Toxicol. 28 (8), 378-385. doi:10.1002/jbt.21574

Khalaf, H. A., and El-Mansy, A. A. E.-R. (2019). The Possible Alleviating Effect of Saffron on Chlorpyrifos Experimentally Induced Cardiotoxicity: Histological, Immunohistochemical and Biochemical Study. Acta Histochem. 121 (4), 472-483. doi:10.1016/j.acthis.2019.03.003

Khezri, S., Sabzalipour, T., Jahedsani, A., Azizian, S., Atashbar, S., and Salimi, A. (2020). Chrysin Ameliorates Aluminum P Hosphide-induced Oxidative Stress and Mitochondrial Damages in Rat Cardiomyocytes and Isolated Mitochondria. Environ. Toxicol. 35 (10), 1114-1124. doi:10.1002/tox.22947

Kim, J.-J., Kim, Y.-S., and Kumar, V. (2019). Heavy Metal Toxicity: An Update of Chelating Therapeutic Strategies. J. Trace Elem. Med. Biol. 54, 226-231. doi:10.1016/j.jtemb.2019.05.003
Kocaadam, B., and Şanlier, N. (2017). Curcumin, an Active Component of Turmeric (Curcuma Longa), and its Effects on Health. Crit. Rev. Food Sci. Nutr. 57 (13), 2889-2895. doi:10.1080/10408398.2015.1077195

Kris-Etherton, P. M. (1999). AHA Science Advisory: Monounsaturated Fatty Acids and Risk of Cardiovascular Disease. J. Nutr. 129 (12), 2280-2284. doi:10.1093/ jn/129.12.2280

Kros, C. J., and Steyger, P. S. (2019). Aminoglycoside- and Cisplatin-Induced Ototoxicity: Mechanisms and Otoprotective Strategies. Cold Spring Harb Perspect. Med. 9 (11), a033548. doi:10.1101/cshperspect.a033548

Kumar, N., Singh, S., Manvi, and Gupta, R. (2012). Trichosanthes Dioica Roxb.: An Overview. Pharmacogn Rev. 6 (11), 61-67. doi:10.4103/09737847.9588610.4103/0973-7847.99898

Kuzu, M., Kandemir, F. M., Yıldırım, S., Çağlayan, C., and Küçükler, S. (2021). Attenuation of Sodium Arsenite-Induced Cardiotoxicity and Neurotoxicity with the Antioxidant, Anti-inflammatory, and Antiapoptotic Effects of Hesperidin. Environ. Sci. Pollut. Res. 28 (9), 10818-10831. doi:10.1007/ s11356-020-11327-5

Li, C., Qu, X., Xu, W., Qu, N., Mei, L., Liu, Y., et al. (2013a). Arsenic Trioxide Induces Cardiac Fibroblast Apoptosis In Vitro and In Vivo by Up-Regulating TGF-B1 Expression. Toxicol. Lett. 219 (3), 223-230. doi:10.1016/ j.toxlet.2013.03.024

Li, M., Jiang, Y., Jing, W., Sun, B., Miao, C., and Ren, L. (2013b). Quercetin Provides Greater Cardioprotective Effect Than its Glycoside Derivative Rutin on Isoproterenol-Induced Cardiac Fibrosis in the Rat. Can. J. Physiol. Pharmacol. 91 (11), 951-959. doi:10.1139/cjpp-2012-0432

Li, R., Kou, X., Geng, H., Xie, J., Tian, J., Cai, Z., et al. (2015). Mitochondrial Damage: an Important Mechanism of Ambient PM2.5 Exposure-Induced Acute Heart Injury in Rats. J. Hazard. Mater. 287, 392-401. doi:10.1016/ j.jhazmat.2015.02.006

Li, X.-N., Zuo, Y.-Z., Qin, L., Liu, W., Li, Y.-H., and Li, J.-L. (2018). Atrazinexenobiotic Nuclear Receptor Interactions Induce Cardiac Inflammation and Endoplasmic Reticulum Stress in Quail (Coturnix coturnix coturnix). Chemosphere 206, 549-559. doi:10.1016/j.chemosphere.2018.05.049

Lin, J., Li, H.-X., Xia, J., Li, X.-N., Jiang, X.-Q., Zhu, S.-Y., et al. (2016). The Chemopreventive Potential of Lycopene against Atrazine-Induced Cardiotoxicity: Modulation of Ionic Homeostasis. Sci. Rep. 6, 24855. doi:10.1038/srep24855

Liu, J., Qu, W., and Kadiiska, M. B. (2009). Role of Oxidative Stress in Cadmium Toxicity and Carcinogenesis. Toxicol. Appl. Pharmacol. 238 (3), 209-214. doi:10.1016/j.taap.2009.01.029

Ma, W., Wei, S., Zhang, B., and Li, W. (2020). Molecular Mechanisms of Cardiomyocyte Death in Drug-Induced Cardiotoxicity. Front. Cel Dev. Biol. 8, 434. doi: $10.3389 /$ fcell.2020.00434

Mahajan, U., Chandrayan, G., Patil, C., Arya, D., Suchal, K., Agrawal, Y., et al. (2017). The Protective Effect of Apigenin on Myocardial Injury in Diabetic Rats Mediating Activation of the PPAR- $\gamma$ Pathway. Ijms 18 (4), 756. doi:10.3390/ ijms 18040756

Mandal, B. K., Ogra, Y., and Suzuki, K. T. (2001). Identification of Dimethylarsinous and Monomethylarsonous Acids in Human Urine of the Arsenic-Affected Areas in West Bengal, India. Chem. Res. Toxicol. 14 (4), 371-378. doi:10.1021/tx000246h

Manna, P., Sinha, M., and Sil, P. C. (2008). Arsenic-induced Oxidative Myocardial Injury: Protective Role of Arjunolic Acid. Arch. Toxicol. 82 (3), 137-149. doi:10.1007/s00204-007-0272-8

Mantawy, E. M., Esmat, A., El-Bakly, W. M., Salah ElDin, R. A., and El-Demerdash, E. (2017). Mechanistic Clues to the Protective Effect of Chrysin against Doxorubicin-Induced Cardiomyopathy: Plausible Roles of P53, MAPK and AKT Pathways. Sci. Rep. 7 (1), 4795. doi:10.1038/s41598-017-05005-9

Mathews, V. V., Paul, M. V., Abhilash, M., Manju, A., Abhilash, S., and Nair, R. H. (2013). Myocardial Toxicity of Acute Promyelocytic Leukaemia Drug-Arsenic Trioxide. Eur. Rev. Med. Pharmacol. Sci. 17 Suppl 1 (Suppl. 1), 34-38.

Mazumder, D. N., Ghosh, A., Majumdar, K., Ghosh, N., Saha, C., and Mazumder, R. N. (2010). Arsenic Contamination of Ground Water and its Health Impact on Population of District of Nadia, west bengal, India. Indian J. Community Med. 35 (2), 331-338. doi:10.4103/0970-0218.66897

McConnell, J. R., and Edwards, R. (2008). Coal Burning Leaves Toxic Heavy Metal Legacy in the Arctic. Proc. Natl. Acad. Sci. 105 (34), 12140-12144. doi:10.1073/ pnas.0803564105 
Mehrpour, O., Neumann, N., and Ng, P. (2019). Is Cytochrome Oxidase Inhibition the Primary Mechanism in Aluminum Phosphide Poisoning? Expert Opin. Drug Metab. Toxicol. 15 (8), 613-614. doi:10.1080/17425255.2019.1645833

Milton Prabu, S., Muthumani, M., and Shagirtha, K. (2013). Quercetin Potentially Attenuates Cadmium Induced Oxidative Stress Mediated Cardiotoxicity and Dyslipidemia in Rats. Eur. Rev. Med. Pharmacol. Sci. 17 (5), 582-595.

Miriyala, S., Chandra, M., Maxey, B., Day, A., St. Clair, D. K., and Panchatcharam, M. (2015). Arjunolic Acid Ameliorates Reactive Oxygen Species via Inhibition of P47 Phox -serine Phosphorylation and Mitochondrial Dysfunction. Int. J. Biochem. Cel Biol. 68, 70-77. doi:10.1016/j.biocel.2015.08.015

Mohammadi, E., Mehri, S., Badie Bostan, H., and Hosseinzadeh, H. (2018). Protective Effect of Crocin against D-Galactose-Induced Aging in Mice. Avicenna J. Phytomed 8 (1), 14-23.

Mohod, S. M., Kandhare, A. D., and Bodhankar, S. L. (2016). Gastroprotective Potential of Pentahydroxy Flavone Isolated from Madhuca Indica J. F. Gmel. Leaves against Acetic Acid-Induced Ulcer in Rats: The Role of OxidoInflammatory and Prostaglandins Markers. J. Ethnopharmacology 182, 150-159. doi:10.1016/j.jep.2016.02.026

Mollaoglu, H., Gokcimen, A., Ozguner, F., Oktem, F., Koyu, A., Kocak, A., et al. (2006). Caffeic Acid Phenethyl Ester Prevents Cadmium-Induced Cardiac Impairment in Rat. Toxicology 227 (1-2), 15-20. doi:10.1016/j.tox.2006.06.020

Mostafalou, S. (2012). Concerns of Environmental Persistence of Pesticides and Human ChronicDiseases. Clin. Exp. Pharmacol. 01 (S5). doi:10.4172/21611459.s5-e02

Mukherjee, A. A., Kandhare, A. D., and Bodhankar, S. L. (2017). Elucidation of Protective Efficacy of Pentahydroxy Flavone Isolated from Madhuca Indica against Arsenite-Induced Cardiomyopathy: Role of Nrf-2, PPAR- $\gamma$, C-Fos and C-Jun. Environ. Toxicol. Pharmacol. 56, 172-185. doi:10.1016/ j.etap.2017.08.027

Muthumani, M., and Prabu, S. M. (2014). Silibinin Potentially Attenuates ArsenicInduced Oxidative Stress Mediated Cardiotoxicity and Dyslipidemia in Rats. Cardiovasc. Toxicol. 14 (1), 83-97. doi:10.1007/s12012-013-9227-x

Muthumani, M., and Prabu, S. M. (2012). Silibinin Potentially Protects ArsenicInduced Oxidative Hepatic Dysfunction in Rats. Toxicol. Mech. Methods 22 (4), 277-288. doi:10.3109/15376516.2011.647113

Nair, A., Degheselle, O., Smeets, K., Van Kerkhove, E., and Cuypers, A. (2013). Cadmium-Induced Pathologies: Where Is the Oxidative Balance Lost (Or Not)? Ijms 14 (3), 6116-6143. doi:10.3390/ijms 14036116

Nath, N. S., Bhattacharya, I., Tuck, A. G., Schlipalius, D. I., and Ebert, P. R. (2011). Mechanisms of Phosphine Toxicity. J. Toxicol. 2011, 1-9. doi:10.1155/2011/ 494168

Nazimabashir, Manoharan, V., and Miltonprabu, S. (2015). Cadmium Induced Cardiac Oxidative Stress in Rats and its Attenuation by GSP through the Activation of Nrf2 Signaling Pathway. Chemico-Biological Interactions 242, 179-193. doi:10.1016/j.cbi.2015.10.005

Ndlovu, S., Pullabhotla, R. V. S. R., and Ntuli, N. R. (2020). Response of Corchorus Olitorius Leafy Vegetable to Cadmium in the Soil. Plants 9 (9), 1200. doi:10.3390/plants9091200

Novelle, M. G., Wahl, D., Diéguez, C., Bernier, M., and de Cabo, R. (2015). Resveratrol Supplementation: Where Are We Now and where Should We Go? Ageing Res. Rev. 21, 1-15. doi:10.1016/j.arr.2015.01.002

Padma, V. V., Poornima, P., Prakash, C., and Bhavani, R. (2013). Oral Treatment with Gallic Acid and Quercetin Alleviates Lindane-Induced Cardiotoxicity in Rats. Can. J. Physiol. Pharmacol. 91 (2), 134-140. doi:10.1139/cjpp-20120279

Paschal, D. C., Burt, V., Caudill, S. P., Gunter, E. W., Pirkle, J. L., Sampson, E. J., et al. (2000). Exposure of the U.S. Population Aged 6 Years and Older to Cadmium: 1988-1994. Arch. Environ. Contam. Toxicol. 38 (3), 377-383. doi:10.1007/s002449910050

Patgiri, B., Umretia, B., Vaishnav, P., Prajapati, P., Shukla, V., and Ravishankar, B. (2014). Anti-inflammatory Activity of Guduchi Ghana (Aqueous Extract of Tinospora Cordifolia Miers.). Ayu 35 (1), 108-110. doi:10.4103/09748520.141958

Peters, J. L., Perlstein, T. S., Perry, M. J., McNeely, E., and Weuve, J. (2010). Cadmium Exposure in Association with History of Stroke and Heart Failure. Environ. Res. 110 (2), 199-206. doi:10.1016/j.envres.2009.12.004

Pichler, G., Grau-Perez, M., Tellez-Plaza, M., Umans, J., Best, L., Cole, S., et al. (2019). Association of Arsenic Exposure with Cardiac Geometry and Left
Ventricular Function in Young Adults. Circ. Cardiovasc. Imaging 12 (5), e009018. doi:10.1161/circimaging.119.009018

Planchart, A., Green, A., Hoyo, C., and Mattingly, C. J. (2018). Heavy Metal Exposure and Metabolic Syndrome: Evidence from Human and Model System Studies. Curr. Envir Health Rpt 5 (1), 110-124. doi:10.1007/ s40572-018-0182-3

Prasanna, N., Krishnan, D. N., and Rasool, M. (2013). Sodium Arsenite-Induced Cardiotoxicity in Rats: Protective Role of P-Coumaric Acid, a Common Dietary Polyphenol. Toxicol. Mech. Methods 23 (4), 255-262. doi:10.3109/ 15376516.2012 .748116

Prasanna, N., and Rasool, M. (2014). Modulation of Gene-Expression Profiles Associated with Sodium Arsenite-Induced Cardiotoxicity by P-Coumaric Acid, a Common Dietary Polyphenol. J. Biochem. Mol. Toxicol. 28 (4), 174-180. doi:10.1002/jbt.21550

Priya, L. B., Baskaran, R., Elangovan, P., Dhivya, V., Huang, C.-Y., and Padma, V. V. (2017). Tinospora Cordifolia Extract Attenuates Cadmium-Induced Biochemical and Histological Alterations in the Heart of Male Wistar Rats. Biomed. Pharmacother. 87, 280-287. doi:10.1016/j.biopha.2016.12.098

Ratnaike, R. N. (2003). Acute and Chronic Arsenic Toxicity. Postgrad. Med. J. 79 (933), 391-396. doi:10.1136/pmj.79.933.391

Razavi, B., Hosseinzadeh, H., Imenshahidi, M., Malekian, M., Ramezani, M., and Abnous, K. (2015). Evaluation of Protein Ubiquitylation in Heart Tissue of Rats Exposed to Diazinon (An Organophosphate Insecticide) and Crocin (An Active Saffron Ingredient): Role of HIF-1a. Drug Res. (Stuttg) 65 (11), 561-566. doi:10.1055/s-0034-1384533

Razavi, B. M., Hosseinzadeh, H., Movassaghi, A. R., Imenshahidi, M., and Abnous, K. (2013). Protective Effect of Crocin on Diazinon Induced Cardiotoxicity in Rats in Subchronic Exposure. Chemico-Biological Interactions 203 (3), 547-555. doi:10.1016/j.cbi.2013.03.010

Razmaraii, N., Babaei, H., Mohajjel Nayebi, A., Assadnassab, G., Ashrafi Helan, J., and Azarmi, Y. (2016). Crocin Treatment Prevents Doxorubicin-Induced Cardiotoxicity in Rats. Life Sci. 157, 145-151. doi:10.1016/j.lfs.2016.06.012

Ren, F., Huang, Y., Tao, Y., Ji, C., Aniagu, S., Jiang, Y., et al. (2020). Resveratrol Protects against PM2.5-induced Heart Defects in Zebrafish Embryos as an Antioxidant rather Than as an AHR Antagonist. Toxicol. Appl. Pharmacol. 398, 115029. doi:10.1016/j.taap.2020.115029

Rikans, L. E., and Yamano, T. (2000). Mechanisms of Cadmium-Mediated Acute Hepatotoxicity. J. Biochem. Mol. Toxicol. 14 (2), 110-117. doi:10.1002/(sici) 1099-0461(2000)14:2<110::aid-jbt7>3.0.co;2-j

Rocha, A., and Trujillo, K. A. (2019). Neurotoxicity of Low-Level lead Exposure: History, Mechanisms of Action, and Behavioral Effects in Humans and Preclinical Models. Neurotoxicology 73, 58-80. doi:10.1016/j.neuro.2019.02.021

Samanta, J., Mondal, A., Saha, S., Chakraborty, S., and Sengupta, A. (2020). Oleic Acid Protects from Arsenic-Induced Cardiac Hypertrophy via AMPK/FoxO/ NFATc3 Pathway. Cardiovasc. Toxicol. 20 (3), 261-280. doi:10.1007/s12012019-09550-9

Samarghandian, S., Farkhondeh, T., and Azimi-Nezhad, M. (2017). Protective Effects of Chrysin against Drugs and Toxic Agents. Dose-Response 15 (2), 155932581771178. doi:10.1177/1559325817711782

Satarug, S. (2018). Dietary Cadmium Intake and its Effects on Kidneys. Toxics 6 (1), 15. doi:10.3390/toxics6010015

Sharma, A. K., Kishore, K., Sharma, D., Srinivasan, B. P., Agarwal, S. S., Sharma, A., et al. (2011). Cardioprotective Activity of Alcoholic Extract of Tinospora Cordifolia (Willd.) Miers in Calcium Chloride-Induced Cardiac Arrhythmia in Rats. J. Biomed. Res. 25 (4), 280-286. doi:10.1016/s16748301(11)60038-9

Sheta, N. M., Elfeky, Y. A., and Boshra, S. A. (2020). Cardioprotective Efficacy of Silymarin Liquisolid in Isoproterenol Prompted Myocardial Infarction in Rats. AAPS PharmSciTech 21 (3), 81. doi:10.1208/s12249-019-1609-3

Shimizu, M., Hochadel, J. F., Fulmer, B. A., and Waalkes, M. P. (1998). Effect of Glutathione Depletion and Metallothionein Gene Expression on ArsenicInduced Cytotoxicity and C-Myc Expression In Vitro. Toxicol. Sci. 45 (2), 204-211. doi:10.1006/toxs.1998.253910.1093/toxsci/45.2.204

Shivakumar, V., Kandhare, A. D., Rajmane, A. R., Adil, M., Ghosh, P., Badgujar, L. B., et al. (2014). Estimation of the Long-Term Cardiovascular Events Using UKPDS Risk Engine in Metabolic Syndrome Patients. Indian J. Pharm. Sci. 76 (2), 174-178.

Shokoohinia, Y., Rashidi, M., Hosseinzadeh, L., and Jelodarian, Z. (2015). Quercetin-3-O- $\beta$-d-glucopyranoside, a Dietary Flavonoid, Protects PC12 
Cells from H2O2-Induced Cytotoxicity through Inhibition of Reactive Oxygen Species. Food Chem. 167, 162-167. doi:10.1016/j.foodchem.2014.06.079

Shou, L., Bei, Y., Song, Y., Wang, L., Ai, L., Yan, Q., et al. (2019). Nrf2 Mediates the Protective Effect of Edaravone after Chlorpyrifos-induced Nervous System Toxicity. Environ. Toxicol. 34 (5), 626-633. doi:10.1002/tox.22728

Singh, D. P., Awasthi, H., Luqman, S., Singh, S., and Mani, D. (2015). Hepatoprotective Effect of A Polyherbal Extract Containing Andrographis Paniculata, Tinospora Cordifolia and Solanum Nigrum against Paracetamol Induced Hepatotoxicity. Pharmacogn Mag. 11 (Suppl. 3), S375-S379. doi:10.4103/0973-1296.168945

Solomon, L. M., Fahrner, L., and West, D. P. (1977). Gamma Benzene Hexachloride Toxicity: a Review. Arch. Dermatol. 113 (3), 353-357. doi:10.1001/archderm.113.3.353

Spencer, C. I., Yuill, K. H., Borg, J. J., Hancox, J. C., and Kozlowski, R. Z. (2001). Actions of Pyrethroid Insecticides on Sodium Currents, Action Potentials, and Contractile Rhythm in Isolated Mammalian Ventricular Myocytes and Perfused Hearts. J. Pharmacol. Exp. Ther. 298 (3), 1067-1082.

Sumitra, M., Manikandan, P., Kumar, D. A., Arutselvan, N., Balakrishna, K., Manohar, B. M., et al. (2001). Experimental Myocardial Necrosis in Rats: Role of Arjunolic Acid on Platelet Aggregation, Coagulation and Antioxidant Status. Mol. Cel Biochem 224 (1-2), 135-142. doi:10.1023/a:1011927812753

Sun, T.-L., Liu, Z., Qi, Z.-J., Huang, Y.-P., Gao, X.-Q., and Zhang, Y.-Y. (2016). (-)-Epigallocatechin-3-gallate (EGCG) Attenuates Arsenic-Induced Cardiotoxicity in Rats. Food Chem. Toxicol. 93, 102-110. doi:10.1016/j.fct.2016.05.004

Suru, S. M. (2008). Onion and Garlic Extracts Lessen Cadmium-Induced Nephrotoxicity in Rats. Biometals 21 (6), 623-633. doi:10.1007/s10534-008-9148-5

Verdura, S., Cuyàs, E., Llorach-Parés, L., Pérez-Sánchez, A., Micol, V., NonellCanals, A., et al. (2018). Silibinin Is a Direct Inhibitor of STAT3. Food Chem. Toxicol. 116 (Pt B), 161-172. doi:10.1016/j.fct.2018.04.028

Visioli, F., Lastra, C. A. D. L., Andres-Lacueva, C., Aviram, M., Calhau, C., Cassano, A., et al. (2011). Polyphenols and Human Health: a Prospectus. Crit. Rev. Food Sci. Nutr. 51 (6), 524-546. doi:10.1080/10408391003698677

Wang, Q., Yang, L., Hua, Y., Nair, S., Xu, X., and Ren, J. (2014). AMP-activated Protein Kinase Deficiency Rescues Paraquat-Induced Cardiac Contractile Dysfunction through an Autophagy-dependent Mechanism. Toxicol. Sci. 142 (1), 6-20. doi:10.1093/toxsci/kfu158

Wang, S., Zhu, X., Xiong, L., and Ren, J. (2017). Ablation of Akt2 Prevents ParaquatInduced Myocardial Mitochondrial Injury and Contractile Dysfunction: Role of Nrf2. Toxicol. Lett. 269, 1-14. doi:10.1016/j.toxlet.2017.01.009
Wang, Y., Fang, J., Leonard, S. S., and Krishna Rao, K. M. (2004). Cadmium Inhibits the Electron Transfer Chain and Induces Reactive Oxygen Species. Free Radic. Biol. Med. 36 (11), 1434-1443. doi:10.1016/j.freeradbiomed.2004.03.010

Xu, D., Hu, M.-J., Wang, Y.-Q., and Cui, Y.-L. (2019). Antioxidant Activities of Quercetin and its Complexes for Medicinal Application. Molecules 24 (6), 1123. doi:10.3390/molecules24061123

Yang, Q., Li, Z., Lu, X., Duan, Q., Huang, L., and Bi, J. (2018). A Review of Soil Heavy Metal Pollution from Industrial and Agricultural Regions in China: Pollution and Risk Assessment. Sci. Total Environ. 642, 690-700. doi:10.1016/ j.scitotenv.2018.06.068

Yordi, E. G., PRez, E., Matos, M. J., and Villares, E. U. (2012). Antioxidant and Prooxidant Effects of Polyphenolic Compounds and Structure-Activity Relationship EvidenceNutrition, Well-Being and Health.

Yu, J., Wang, C., Kong, Q., Wu, X., Lu, J.-J., and Chen, X. (2018). Recent Progress in Doxorubicin-Induced Cardiotoxicity and Protective Potential of Natural Products. Phytomedicine 40, 125-139. doi:10.1016/j.phymed.2018.01.009

Zabaiou, N., Fouache, A., Trousson, A., Baron, S., Zellagui, A., Lahouel, M., et al. (2017). Biological Properties of Propolis Extracts: Something New from an Ancient Product. Chem. Phys. Lipids 207 (Pt B), 214-222. doi:10.1016/ j.chemphyslip.2017.04.005

Zhang, L., Feng, Q., and Wang, T. (2018). Necrostatin-1 Protects against ParaquatInduced Cardiac Contractile Dysfunction via RIP1-RIP3-MLKL-dependent Necroptosis Pathway. Cardiovasc. Toxicol. 18 (4), 346-355. doi:10.1007/ s12012-017-9441-z

Zhang, W., Xiao, X., Peng, C., Chen, W., Xie, S., and Wang, D. (2019). Sodium Tanshinone IIA Sulfate Protects Myocardium against Paraquat-Induced Toxicity through Activating the Nrf2 Signaling Pathway in Rats. Hum. Exp. Toxicol. 38 (2), 247-254. doi:10.1177/0960327118792051

Conflict of Interest: The authors declare that the research was conducted in the absence of any commercial or financial relationships that could be construed as a potential conflict of interest.

Copyright $\odot 2021$ Yang, Wei, Zhang and Li. This is an open-access article distributed under the terms of the Creative Commons Attribution License (CC BY). The use, distribution or reproduction in other forums is permitted, provided the original author(s) and the copyright owner(s) are credited and that the original publication in this journal is cited, in accordance with accepted academic practice. No use, distribution or reproduction is permitted which does not comply with these terms. 